Article

\title{
Analytical Fragility Curves of Pile Foundations with Soil-Structure Interaction (SSI)
}

\author{
Davide Forcellini (D)
}

check for updates

Citation: Forcellini, D. Analytical Fragility Curves of Pile Foundations with Soil-Structure Interaction (SSI). Geosciences 2021, 11, 66. https:// doi.org/10.3390/geosciences11020066

Academic Editors:

Jesus Martinez-Frias and Salvatore Grasso

Received: 8 December 2020

Accepted: 30 January 2021

Published: 3 February 2021

Publisher's Note: MDPI stays neutral with regard to jurisdictional claims in published maps and institutional affiliations.

Copyright: (C) 2021 by the author. Licensee MDPI, Basel, Switzerland. This article is an open access article distributed under the terms and conditions of the Creative Commons Attribution (CC BY) license (https:/ / creativecommons.org/licenses/by/ $4.0 /)$.
Department of Civil and Environmental Engineering, University of Auckland, 20 Symonds Street, Auckland 1010, New Zealand; dfor295@aucklanduni.ac.nz

\begin{abstract}
Pile foundations is a well-studied technique with many applications and its benefits on structures have been widely studied in the literature. In particular, the mutual effects of pile flexibility and soil deformability may significantly modify the seismic behaviour of superstructures. In order to consider the uncertainties that are connected with these issues, the paper applies the probabilistic-based approach of fragility curves by proposing three limit states based on ductility factor. Non-linear dynamic analyses were performed with OpenSees PL to assess the potentialities of three pile configurations founded on three cohesionless soil with different deformability.
\end{abstract}

Keywords: soil structure interaction; analytical fragility curves; pile foundation; ductility factor; numerical simulations; Opensees

\section{Introduction}

The role of Soil Structure Interaction (SSI) is fundamental to define the seismic fragility of pile foundations that depend on the mutual flexibility of the pile and soil and the location and length of the plastic hinges. Inelastic responses and damage mechanisms of laterally loaded piles have been described in the literature (i.e., [1,2]). In particular, [3] describes in detail the development of yielding points along the piles due to lateral seismic forces. Pile flexibility drives the seismic response of entire systems (soil-foundation-structure) as demonstrated in previous earthquakes $[4,5]$ and investigated in several contributions, such as [6]. Since inelastic deformations may occur in inaccessible areas (with no visual inspection), stringent ductility limits need to be defined as prescribed by [7] and the New Zealand provisions for the seismic design of highway bridge foundations [8].

Many contributions have aimed to investigate pile foundation responses under seismic loading conditions considering experimental tests such as $[9,10]$ that performed centrifuge studies or [11] that carried out shaking table tests. In addition, analytical methodologies were proposed such as [12] that developed an exact formulation for a piled raft system resting on elastic Winkler foundations.

Numerical studies were also performed from the first attempts (i.e., [13] that applied the Winkler modelling approach). Several contributions performed numerical simulations of the inelastic deformation and displacement ductility of laterally loaded piles, such as [14,15] that adopted the beam-on-Winkler-foundation model. The authors of [16] applied a kinematic cantilever model and [17] focused on the inelastic seismic response of bridges supported by free-standing extended pile-shafts. The authors of [18,19] performed numerical simulations to assess the displacement ductility capacity of fixed-head piles in cohesive soils. Recent contributions were based on more developed platforms, such as [20-22]. 2D finite elements were performed by [23] that applied the DYNAFLOW platform, [24] that carried out nonlinear plane-strain seismic analyses and more recently by [25] that performed a fully nonlinear 2D FE study with several pile-deck connections. Several 3D finite element models were conducted, such as [26] that investigated the Port of Oakland Berth recorded seismic response and [27] for a push-over seismic evaluation study. In addition, several studies applied Opensees such as [28] and the more recent [29] 
that assessed the salient characteristics associated with the pile-ground and pile-to-pile interaction mechanisms. More recently, [30] adapted the previous kinematic model [3] to assess the displacement ductility factors for piles foundations in cohesionless soils. Many numerical models (i.e., [31-36]) applied deterministic approaches that may not account for the uncertainties related with modelling of SSI $([37,38])$.

In this regards, even if fragility curve is a well-known approach to assess the structural damage of various systems $([39,40]$, very few contributions have applied this method to assess pile foundations. In particular, [41] applied Opensees to develop fragility curves for a typical wharf structure, [42] derived fragility curves of 3D models of buildings considering (among the others) a pile foundation system with soil-pile interaction modelled through a 2D finite element soil-block. The authors of [43] performed seismic fragility analyses for a case study of sheet-pile wharves in Port of Hualien in Taiwan by applying the FEA software PLAXIS 2D. The recent [44] applied the methodology to pile foundations of unreinforced masonry (URM) buildings in the Groningen region (northern Netherlands) by proposing hysteretic single-degree-of-freedom (SDOF) models by applying the cloud method with linear regression and Conditional Spectrum (CS) for the ground motion selection.

The present paper aims to propose the fragility curves of single-pile schemes founded on different sand layers characterized by increasing soil deformability. Secondly, it is well noted that the mechanism of piles depends on their flexibility in terms of L/D (ratio between pile length and pile diameter) that is fundamental to define the performance of the entire pile-foundation-soil system. Therefore, the paper proposes several case studies of pile foundations characterized by different values of L/D to assess the mutual role of pile flexibility and soil deformability on the entire system (soil-pile-superstructure).

\section{Methodology}

This paper aims to investigate the performance of three pile configurations with different flexibility ( $\mathrm{L} / \mathrm{D}=5,10$ and 20). The behaviours of the piles depend on the mutual behaviour between the piles and the soil, the so-called kinematic interaction that consists of a series of complex non-linear mechanisms that may be activated by an earthquake [45]. Overcoming the previous contributions that considered deterministic approaches, the paper applies analytical fragility curves as a probabilistic-based methodology to express the probability of damage at certain levels of intensities by defining damage states (DS). They represent graphical relationships between the conditional probability of exceeding predefined damage states (DS) for given levels of EDP (engineering demand parameters) and are used to estimate the amount of damage for a particular level of shaking defined with intensity measures (IM).

In particular, for pile foundations, inelastic deformations are due to displacements imposed on the foundation, the mutual stiffness and strength of the pile and soil, and the location and length of the plastic hinges. Therefore, the definition of damage levels is particularly challenging since it depends on the pile flexural yielding. This paper applies the Ductility Factor (DF) proposed by [30] as the reference parameter to define limit states. In particular, the depth at which pile yielding is expected to occur is fundamental to defining the design ductility factor. For example, the seismic design of highway bridge foundations in New Zealand [8] consider several design displacement ductility factors taking $2 \mathrm{~m}$ as the reference depth. In this paper, the equivalent elastoplastic yield displacement $\Delta y$ was idealized by considering a bilinear elastoplastic force-displacement response of the pile. Therefore, the ductility factor DF is defined as the ratio of the ultimate displacement $(\Delta \mathrm{u})$ and the elastoplastic yield displacement $(\Delta y)$ :

$$
\mathrm{DF}=\frac{\Delta \mathrm{u}}{\Delta \mathrm{y}}
$$

where the ultimate displacement $\Delta \mathbf{u}$ was calculated as the maximum lateral displacement for each of the applied input motions and the yield displacement is calculated by considering the expected yield strength of the reinforcement, calculated as: 


$$
\mathrm{f}_{\mathrm{ye}}=1.13 \mathrm{f}_{\mathrm{y}}
$$

where $\mathrm{f}_{\mathrm{y}}$ is the steel yield strength.

In particular, Limit State 3 (LS3) was defined for DF $=2$, proposed herein as a design value to ensure good seismic performance of the pile for soils with friction angle between $30^{\circ}$ and $33^{\circ}$ [30]. A moderate level (LS2) was proposed here as $50 \%$ of the previous value $(\mathrm{DF}=1)$ and a slight level (LS1) with $\mathrm{DF}=0.30$. The adopted methodology is based on the calculation of linear regressions to define the logarithmic mean $(\mu)$ and standard deviation $(\beta)$ of the Peak Ground Acceleration (PGA), selected as the representative intensity measure (IM).

The seismic scenario is described by the longitudinal component of 100 input motions, selected from the PEER NGA database (http:/ / peer.berkeley.edu/nga/) and applied at the base of the models. The motions were divided into 5 bins of 20 motions each with characteristics: moment magnitude (Mw) 6.5-7.2 and closest distance (R) 15-30 km, Mw 6.5-7.2 and R 30-60 km, Mw 5.8-6.5 and R 15-30 km, Mw 5.8-6.5 and R 30-60 km, and Mw 5.8-7.2 and R 0-15 km, as already applied in [46]. Figure 1 shows the cumulative density functions (CDFs) of the 100 motions and for the Peak Ground Acceleration (PGA) selected as the reference intensity measure. In particular, fragility may be defined as the conditional probability of failure for selected parameters in order to account for several sources of uncertainty (i.e., modelling, representation of the demand and capacity, soil parameters). In the proposed study the only random parameter is the seismic demand that is described with PGA. The set of input motions was selected following Eurocode 8 (CEN, 2003, [47]): (1) it consists of at least seven recordings and (2) the average spectral ordinates of the selected record set were matched to the target code-based spectral shape. The set was selected to have significantly dispersed values of intensities to affect the dynamic characteristics of the system and at each acceleration value a, the fragility was represented by a subjective probability density function.

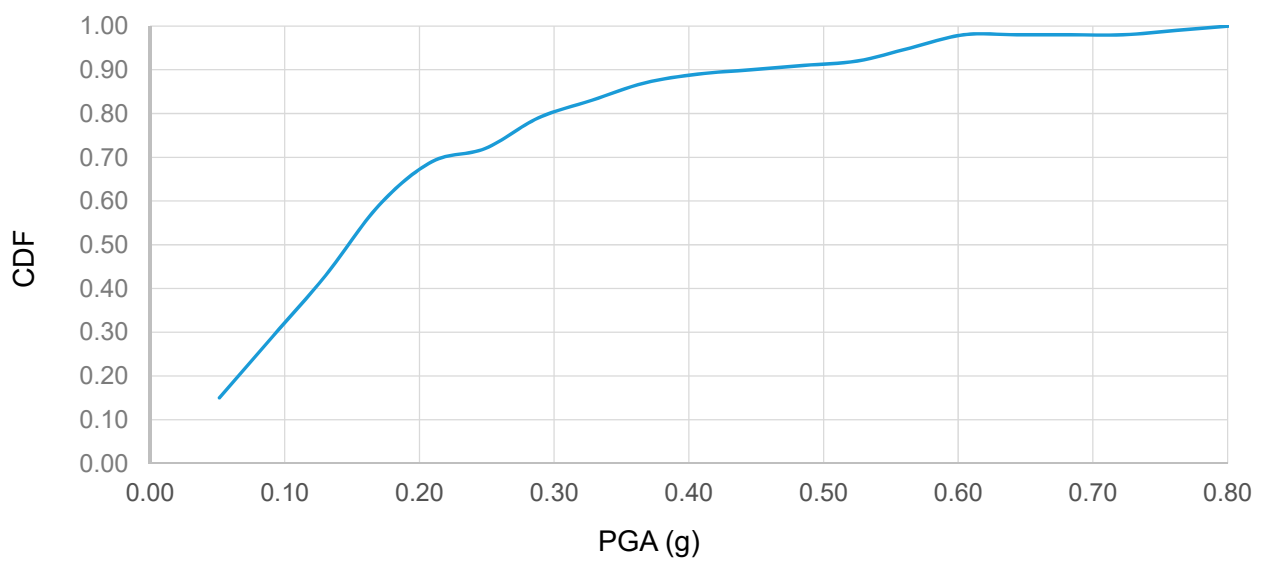

Figure 1. Cumulative distributions for the considered IM: PGA.

\section{Finite Elements Models}

This paper aims to study single piles as parts of a group of piles (i.e., Figure 2). 100 non-linear dynamic analyses were performed with parallel computation by applying the well-credited platform Opensees PL [48]. Computational time was reasonably controlled (less than $72 \mathrm{~h}$ ) by considering some assumptions: (1) The $25 \mathrm{~m}$ layer was considered homogeneous for each of the three selected soils (see below). (2) Symmetry conditions were considered, allowing to investigate a representative "cell", following the approach already performed in [28] (Figure 3). (3) Pile deformations were calculated at every points during the analyses but saved only at specific sections along the pile. (4) A bilinear material (fy $=420 \mathrm{MPa}, \mathrm{f}^{\prime} \mathrm{c}=34.5 \mathrm{MPa}$ ) was used to represent the concrete. 


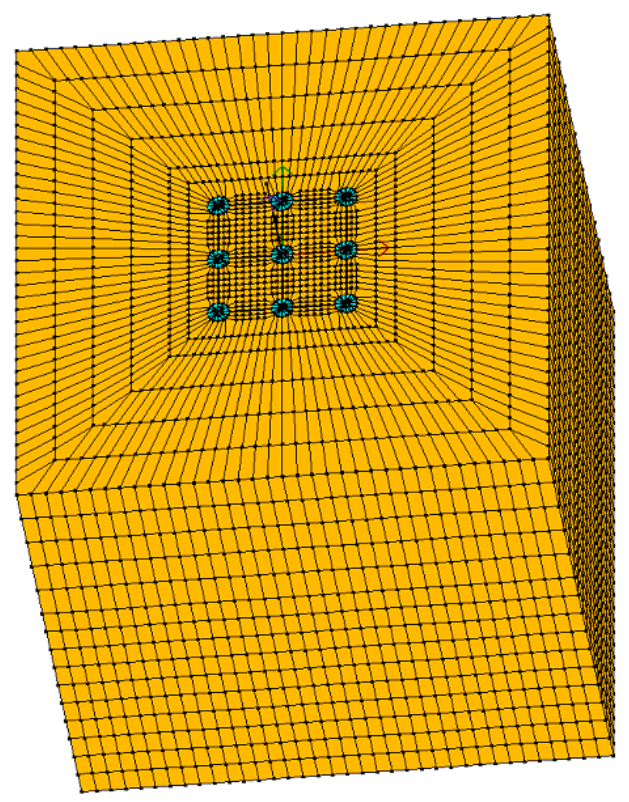

Figure 2. Example of a full 3D mesh.

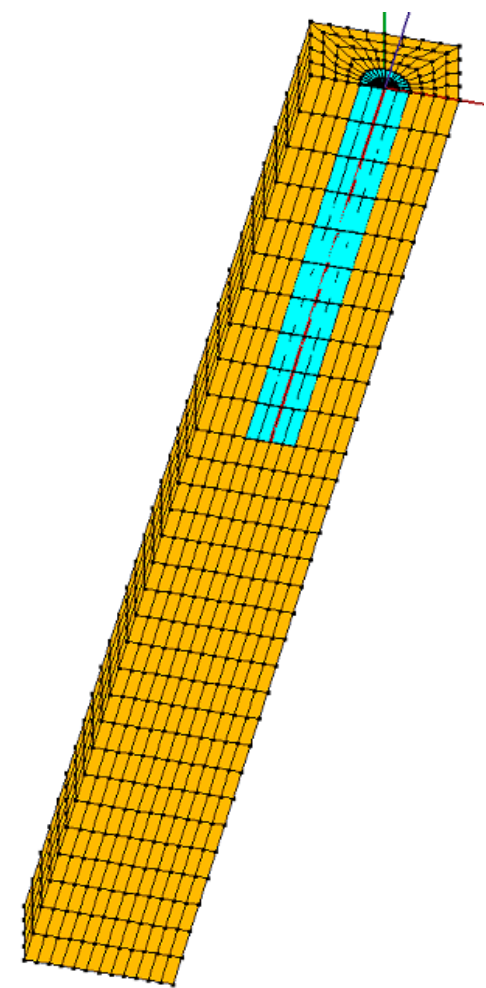

(a)

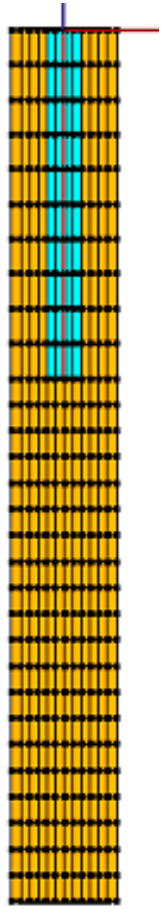

(b)

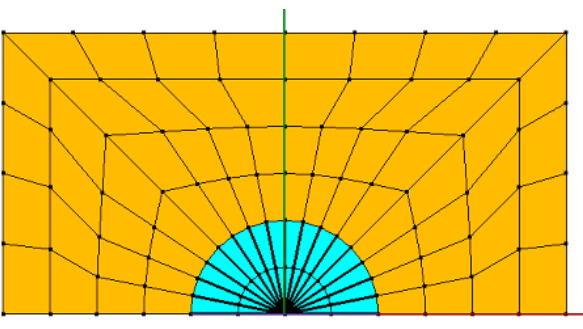

(c)

Figure 3. Cell mesh: (a) 3D view, (b) vertical view, (c) plan view.

The half-mesh of the representative cell of soil was constrained with the periodicboundary technique, thanks to symmetry conditions (see simplification 2), as shown in [49]. Accounting for the symmetry, left and right boundary nodes were tied together both longitudinally and vertically using the penalty method [50] with $10^{-4}$ tolerance, as a compromise (more details in $[51,52]$ ). The circular piles were modelled with 3D fiber sections, force-based beam-column elements [48]. As mentioned earlier, concrete materials for the core and the cover portions of the cross sections have been modelled with bilinear 
relationships to reduce computational time and define yielding conditions. Steel bars were modelled with Steel02 material [50]. Figure 4 shows the moment-curvature response (the same in all directions because of the circular shape) of the pile cross section under the constant axial load P defined in Table 1 (formula 3). The interaction between the pile and the soil was realized with zerolenght elements [50] that connect the soil domain 3D brick elements at the outer nodes of the rigid beam-column links (set normal to the pile longitudinal axis) by allowing the relative soil-pile displacements (slippage) that affects considerably SSI effects mainly under large deformations.

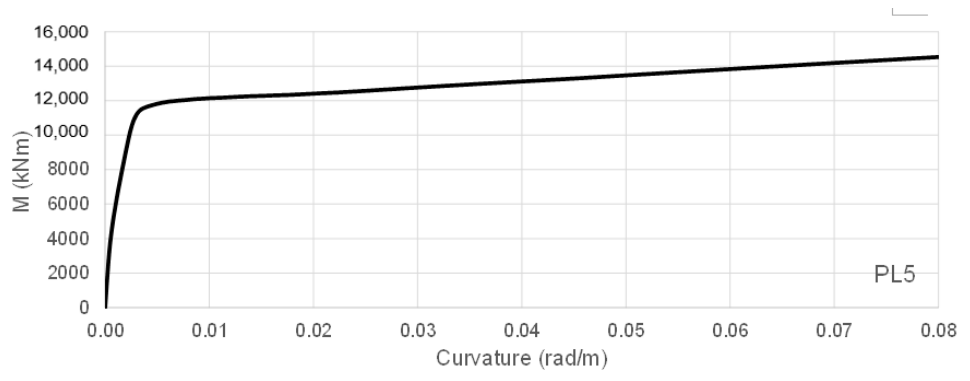

(a)

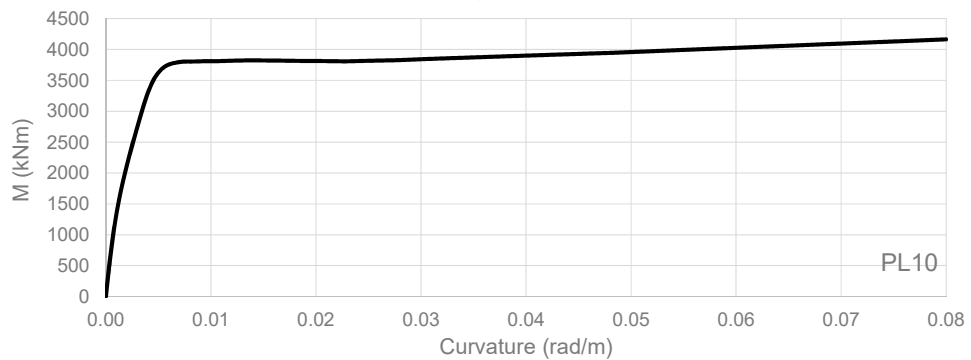

(b)

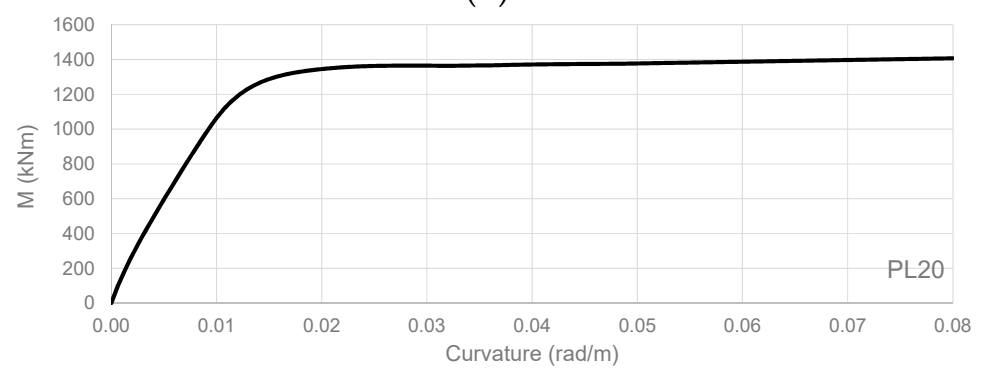

(c)

Figure 4. Moment-curvature for: (a) PL5, (b) PL10, (c) PL20.

Table 1. Piles Characteristics.

\begin{tabular}{ccccccc}
\hline & $\mathbf{D}(\mathbf{m})$ & $\mathbf{L}(\mathbf{m})$ & $\mathbf{L} / \mathbf{D}$ & $\mathbf{A g}\left(\mathbf{m}^{\mathbf{2}}\right)$ & $\mathbf{I ~}_{\left(\mathbf{m}^{\mathbf{4}}\right)}$ & $\mathbf{P}(\mathbf{M P a})$ \\
\hline PL5 & 2.0 & 10.0 & 5 & 3.142 & 0.785 & 2.03 \\
PL10 & 1.0 & 10.0 & 10 & 0.785 & 0.049 & 8.12 \\
PL20 & 0.5 & 10.0 & 20 & 0.196 & 0.003 & 32.50 \\
\hline
\end{tabular}

The piles were loaded with a vertical axial force defined as the $30 \%$ of the axial load capacity, generally considered for normal design of concrete piles [30]:

$$
\mathrm{P}=0.30 \mathrm{f}_{\mathrm{c}}^{\prime} \mathrm{A}_{\mathrm{g}}
$$

where: Ag is the gross cross sectional area of the pile; and $\mathrm{f}^{\prime} \mathrm{c}$ the concrete compressive strength (34.5 MPa). 
The soil mesh was built up with 3193 nodes and 2640 non-linear "Bbar brick" elements and was calibrated with a convergence study as a compromise between the MESH1 (2139 nodes and 1680 elements) and MESH3 (9331 nodes and 8280 elements), by comparing the longitudinal displacement at the center of the pile at surface level (Figure 5). The meshes were tested by verifying that the accelerations at the surface of the mesh near the lateral boundaries were identical to those simulating free-field conditions.
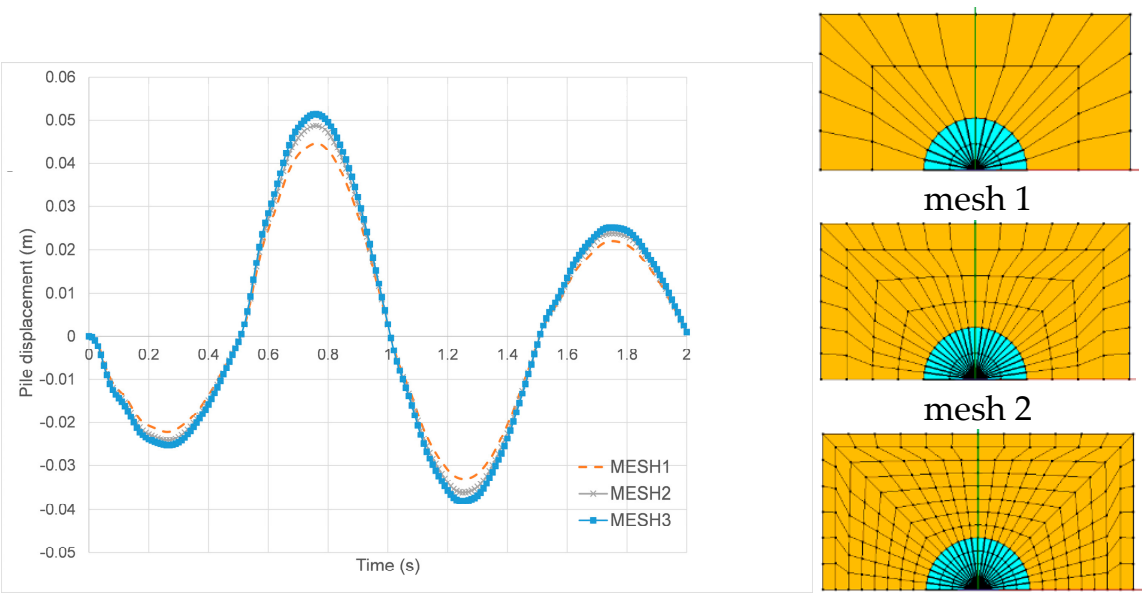

mesh 3

Figure 5. Convergence Study: longitudinal displacements at the center of the pile at surface level (for mesh1, mesh2 and mesh3).

Every element is built with 20 nodes with three translational Degree of Freedom (DOF), recorded using OpenSees Node Recorder [50] at the corresponding integration points. The number of elements was defined on the bases of the wavelength of the seismic signal and the maximum frequency $(15 \mathrm{~Hz})$ above which the spectral content of the input may be considered negligible [53]. Following [54], the characteristics of the input motions (i.e., wavelength and maximum frequency) were used to define the number of elements whose dimensions were increased with the distance to the centre of the piles. Lysmer-Kuhlemeyer (L-K) viscous dashpots [55] were defined at the base boundaries (along the longitudinal direction) to accurately model radiation damping so as to prevent the reflection of the seismic waves back into the soil medium after being incident on the far-off boundaries. Three 25m-homogeneous cohesionless dry (no pore pressure) layers (named STIFF, MEDIUM and SOFT) with different increasing deformability were performed to consider the non-linear effects of the soil, such as amplitude-dependent amplification (or deamplifications), plastic accumulations of ground deformation, and permanent movements (rotations, longitudinal displacements) at the pile level. The PressureDependMultiYield (PDMY) model was applied in order to consider the non-linear mechanisms of hysteretic response and radiation damping based on the multisurface-plasticity theory for frictional cohesionless soils proposed by [56]; more details in [48]. Figure 6 shows the non-linear backbone curves, represented by hyperbolic relations defined by the strain shear modulus and ultimate shear strength, as described in [48]. The representative parameters are shown in Table 2.

Table 2. Soil Parameters (PDMY model).

\begin{tabular}{cccc}
\hline & Stiff & Medium & Soft \\
\hline Mass density $\left(\mathrm{kN} / \mathrm{m}^{3}\right)$ & 20 & 19 & 17 \\
Shear Modulus $(\mathrm{kPa})$ & $1.0 \times 10^{5}$ & $7.7 \times 10^{4}$ & $5.8 \times 10^{4}$ \\
Bulk Modulus $(\mathrm{kPa})$ & $3.1 \times 10^{5}$ & $2.2 \times 10^{5}$ & $1.75 \times 10^{5}$ \\
Friction Angle $\left(^{\circ}\right)$ & 37 & 33 & 29 \\
Num. Yield Surface & 20 & 20 & 20 \\
\hline
\end{tabular}




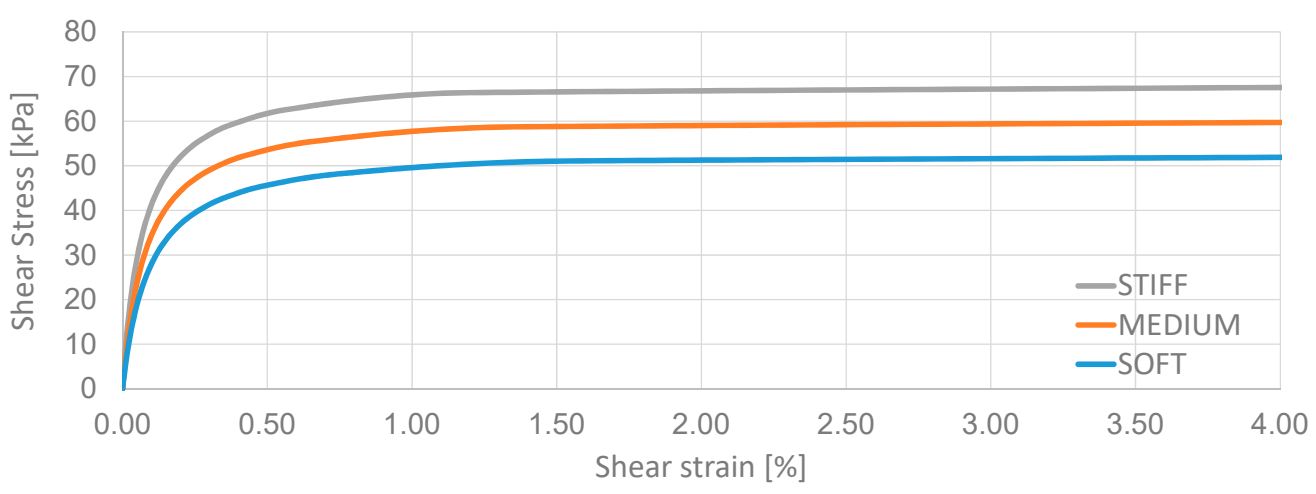

Figure 6. Backbone curves.

\section{Results}

In this section, the results are shown and discussed. Figures 7-9 show the results of the $900(100 \times 3: 100$ for each of the selected pile cases and for the 3 soil conditions $)$ non-linear analyses with the considered limit states. Soft soil was shown to be the most detrimental condition for all the models.

The results were applied to build linear regressions ( $R^{2}$ values in Table 3$)$ and calculate the logarithmic mean $(\mu)$ and standard deviation $(\beta)$ of PGA, necessary to define the probability of exceedance (PE):

$$
\mathrm{P}[\mathrm{D} \geq \mathrm{Ci} \mid \mathrm{PGA}]=\phi\left(\frac{\ln (\mathrm{PGA})-\mu}{\beta}\right)
$$

where: $\mathrm{P}$ is the probability of the structural damage (D) exceeding the i-th damage state (C); $\phi$ is the standard normal cumulative distribution function;

Table 3. $R^{2}$ values.

\begin{tabular}{cccc}
\hline & Stiff & Medium & Soft \\
\hline PL5 & 0.875 & 0.896 & 0.719 \\
PL10 & 0.559 & 0.591 & 0.547 \\
PL20 & 0.872 & 0.871 & 0.709 \\
\hline
\end{tabular}

PL5

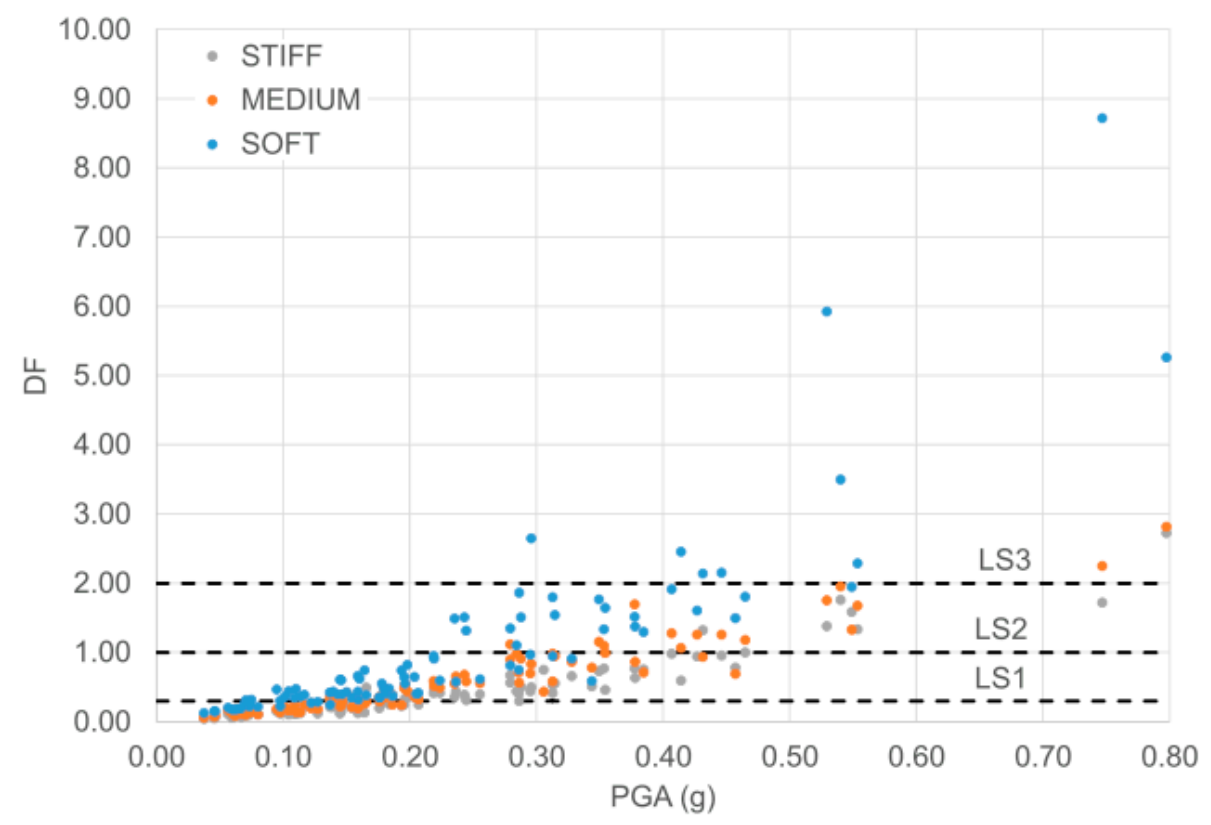

Figure 7. PL5: PGA(g) vs. Ductility Factor. 


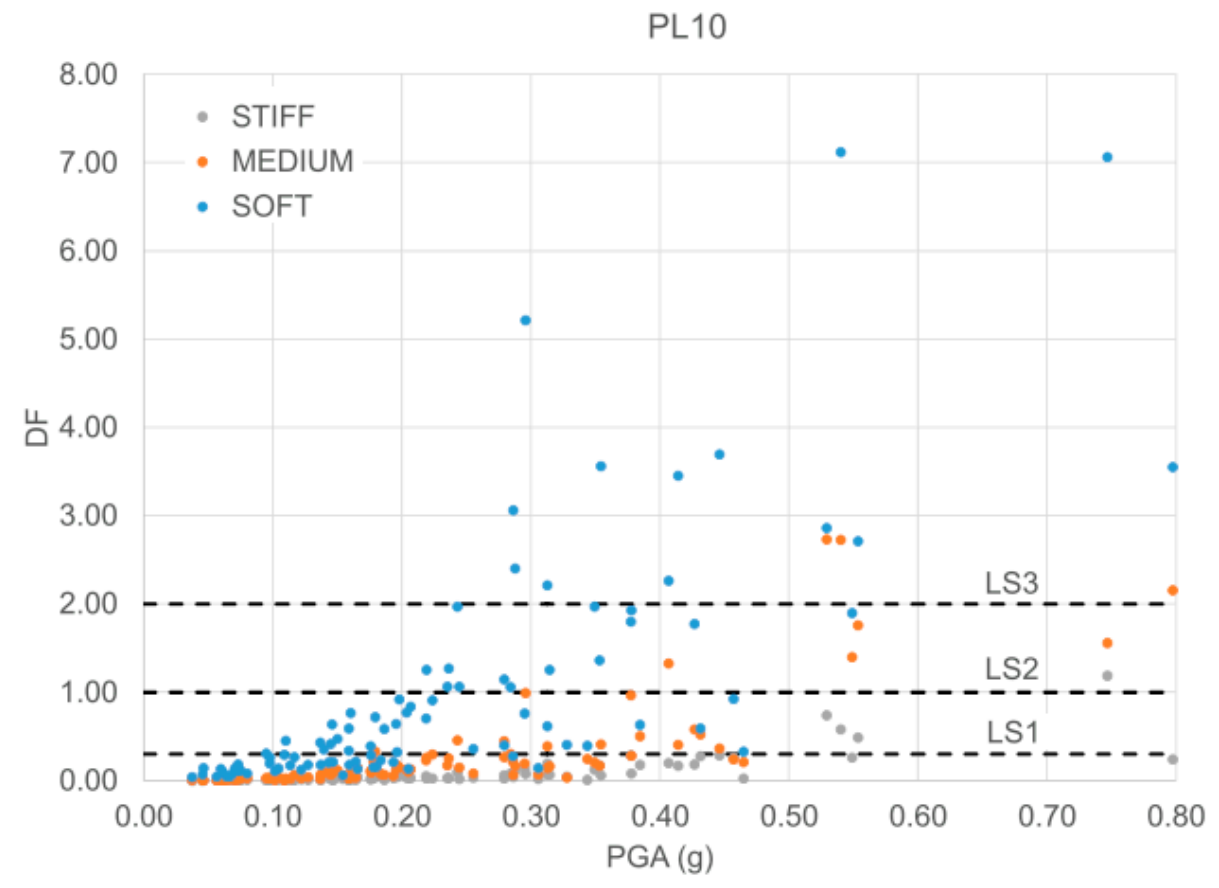

Figure 8. PL10: PGA(g) vs. Ductility Factor.

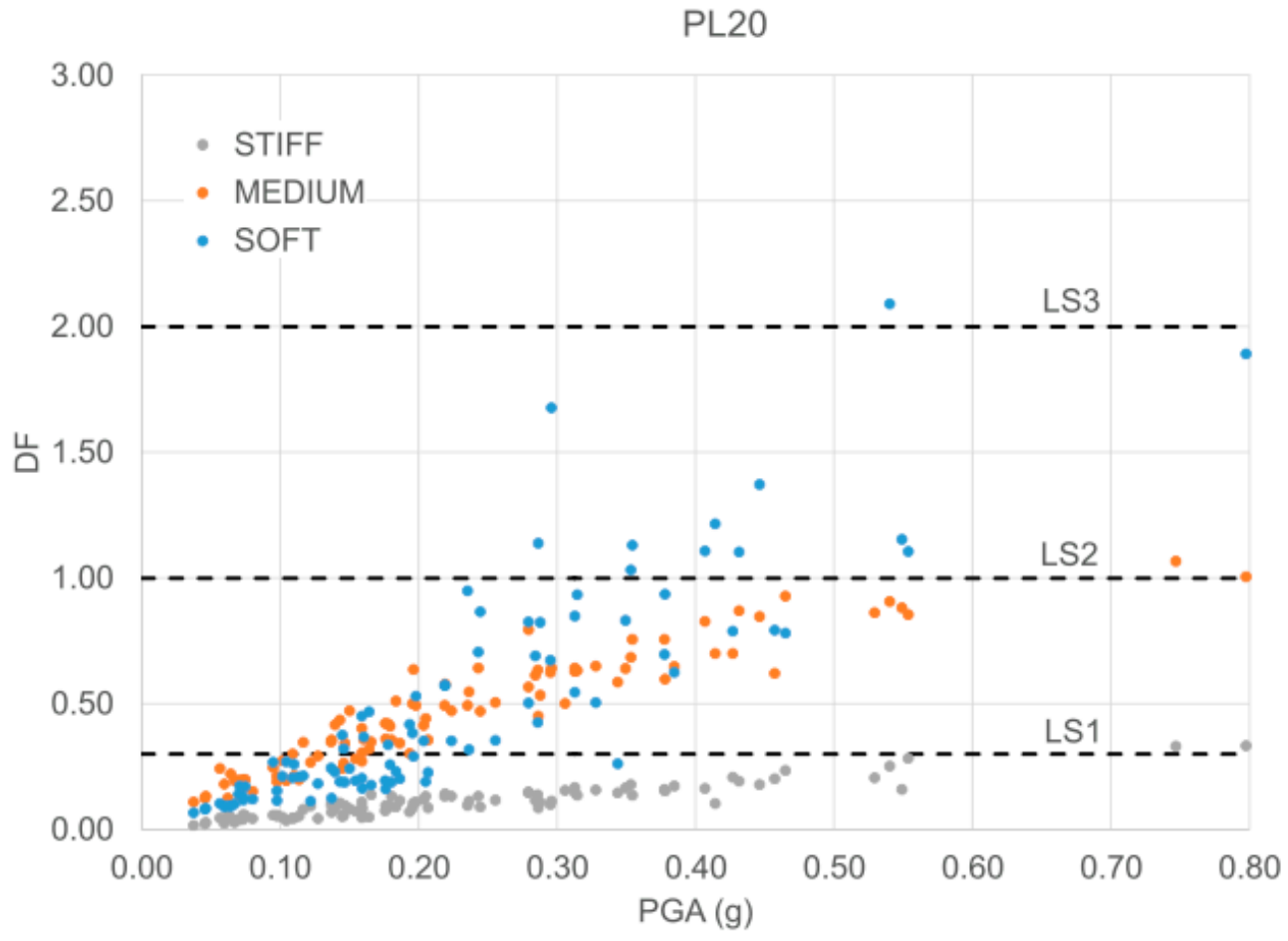

Figure 9. PL20: PGA(g) vs. Ductility Factor.

4.1. PL10

This section shows the results for PL10 in terms of fragility curves, as defined in the previous section. In particular, Tables $4-6$ show $\mu$ and $\beta$ values for the considered soil conditions. It is worth noting that the standard deviation affects the slope of the curves while the mean values increase with soil deformability, shifting the curves toward more vulnerable responses. 
Table 4. PL10 STIFF: lognormal parameters.

\begin{tabular}{cccc}
\hline Parameter & LS1 & LS2 & LS3 \\
\hline$\mu$ & $0.173 \mathrm{~g}$ & $0.180 \mathrm{~g}$ & - \\
$\beta$ & 0.634 & 0.654 & - \\
\hline
\end{tabular}

Table 5. PL10 MEDIUM: lognormal parameters.

\begin{tabular}{cccc}
\hline Parameter & LS1 & LS2 & LS3 \\
\hline$\mu$ & $0.154 \mathrm{~g}$ & $0.165 \mathrm{~g}$ & $0.180 \mathrm{~g}$ \\
$\beta$ & 0.577 & 0.606 & 0.640 \\
\hline
\end{tabular}

Table 6. PL10 SOFT: lognormal parameters.

\begin{tabular}{cccc}
\hline Parameter & LS1 & LS2 & LS3 \\
\hline$\mu$ & $0.109 \mathrm{~g}$ & $0.146 \mathrm{~g}$ & $0.165 \mathrm{~g}$ \\
$\beta$ & 0.509 & 0.576 & 0.609 \\
\hline
\end{tabular}

The role of SSI effects at different intensities for PL 10 is shown in Figures 10-12. When STIFF conditions are considered (Figure 10) the probability of exceedance (PE) does not depend on the limit states, meaning that the level of damage is very low (compared with Figure 8) and LS3 is not reached under stiff conditions (Figure 10). For medium and soft conditions, DF is more distributed and fragility curves for the various LS are sparser. For example, for soft conditions, the PE of 50\% (mean value, see Table 6) is reached for $0.109 \mathrm{~g}$, $0.146 \mathrm{~g}$, and $0.165 \mathrm{~g}$, respectively for LS1, LS2, and LS3.

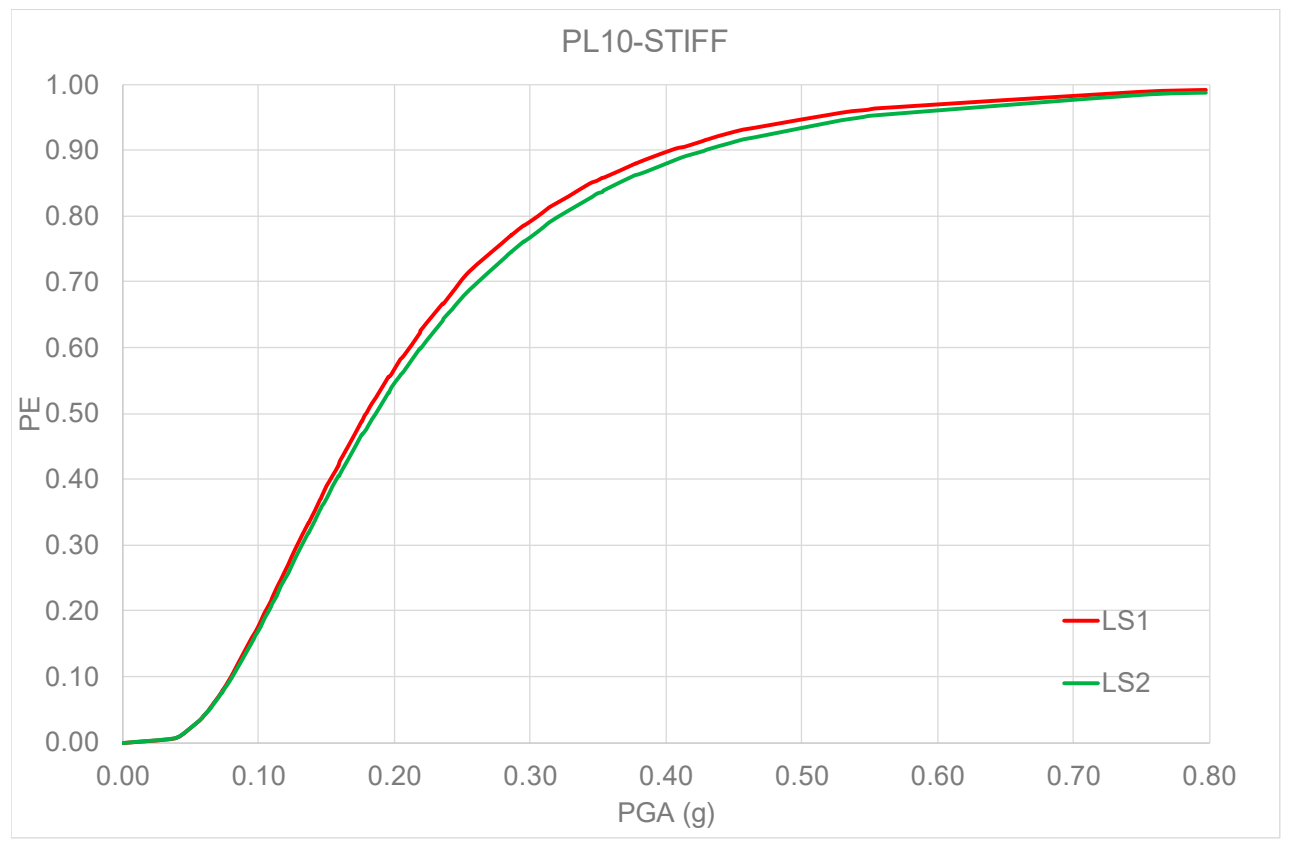

Figure 10. PL10-STIFF: PGA (g) vs. Probability of exceedance (PE). 


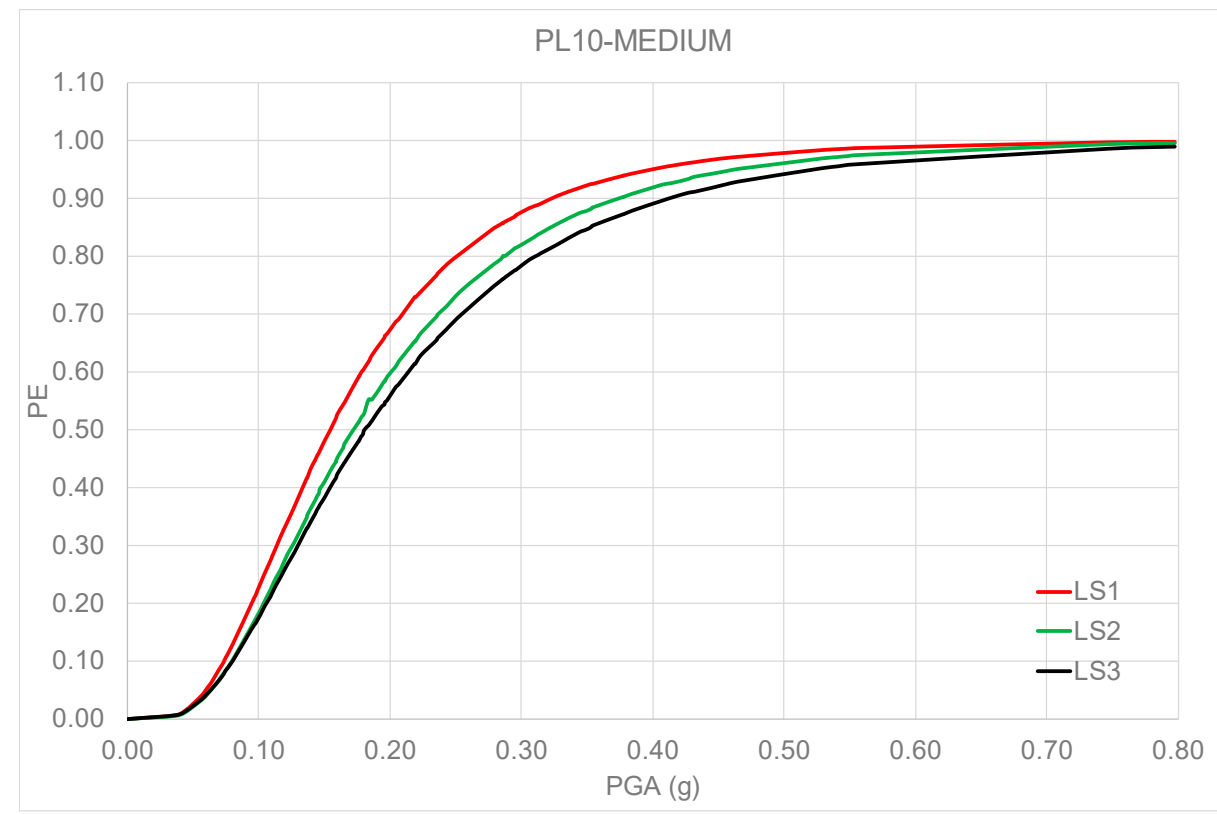

Figure 11. PL10-MEDIUM: PGA (g) vs. Probability of exceedance (PE).

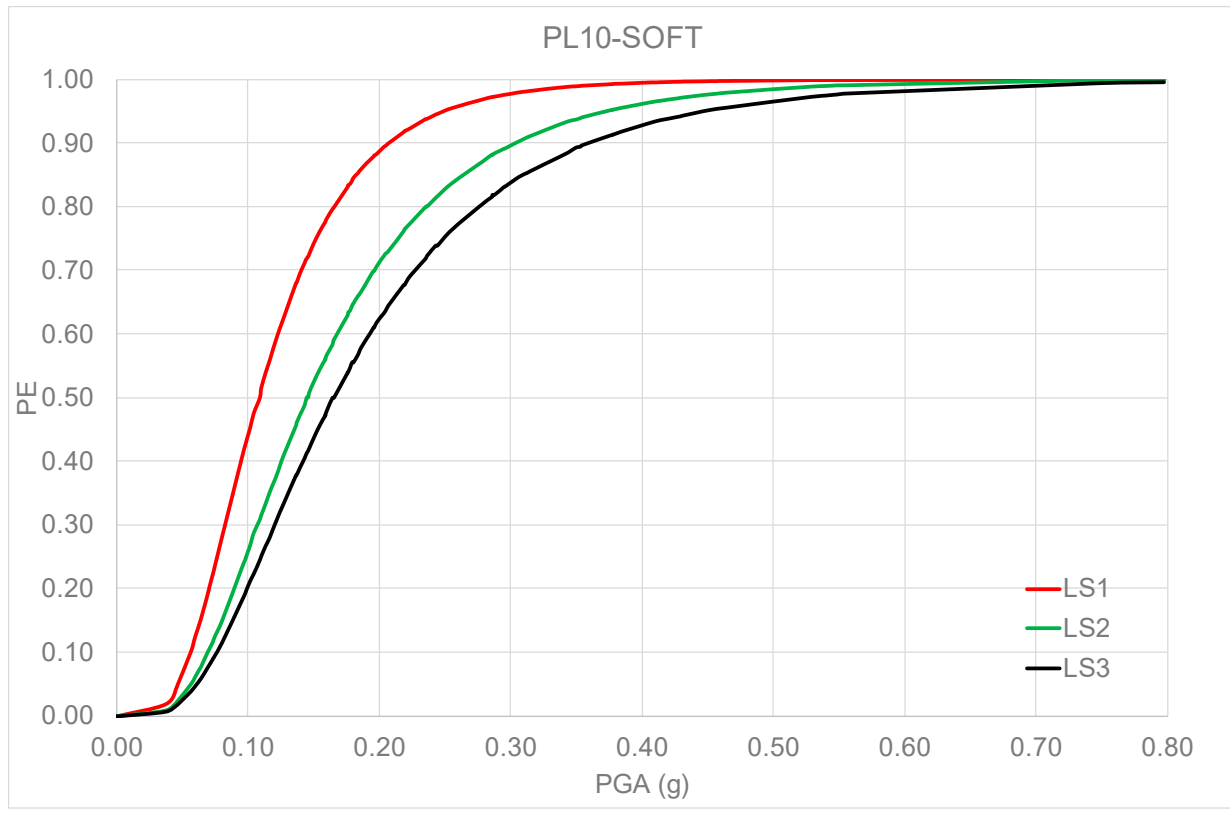

Figure 12. PL10-SOFT: PGA (g) vs. Probability of exceedance (PE).

If the same LS are compared for different soil deformability (Figures 13-15), it is possible to see the effects of SSI in increasing the damage. In particular, Figure 13 shows that soil deformability is relevant for the first part of the curves (below $0.40 \mathrm{~g}$ ), while for bigger intensities, the curves are less influenced by SSI. For example, for LS1 and PGA $=0.20 \mathrm{~g}$, PE values are $0.560,0.666$ and 0.894 , for stiff, medium and soft conditions, respectively. For LS2, soil deformability is also significant with a maximum difference for PGA $=0.20$ g: $0.539,0.590$ and 0.705 for stiff, medium and soft conditions, respectively For LS3 (Figure 15), stiff conditions do not reach the limit state and the difference between medium and soft conditions are still important (i.e., for PE values are PGA $=0.20 \mathrm{~g}: 0.552$ and 0.633 for medium and soft conditions, respectively), see Table 7 . 
Table 7. PL10 (PGA: 0.20 g).

\begin{tabular}{cccc}
\hline PE & LS1 & LS2 & LS3 \\
\hline STIFF & 0.560 & 0.539 & - \\
MEDIUM & 0.666 & 0.590 & 0.552 \\
SOFT & 0.894 & 0.705 & 0.633 \\
\hline
\end{tabular}

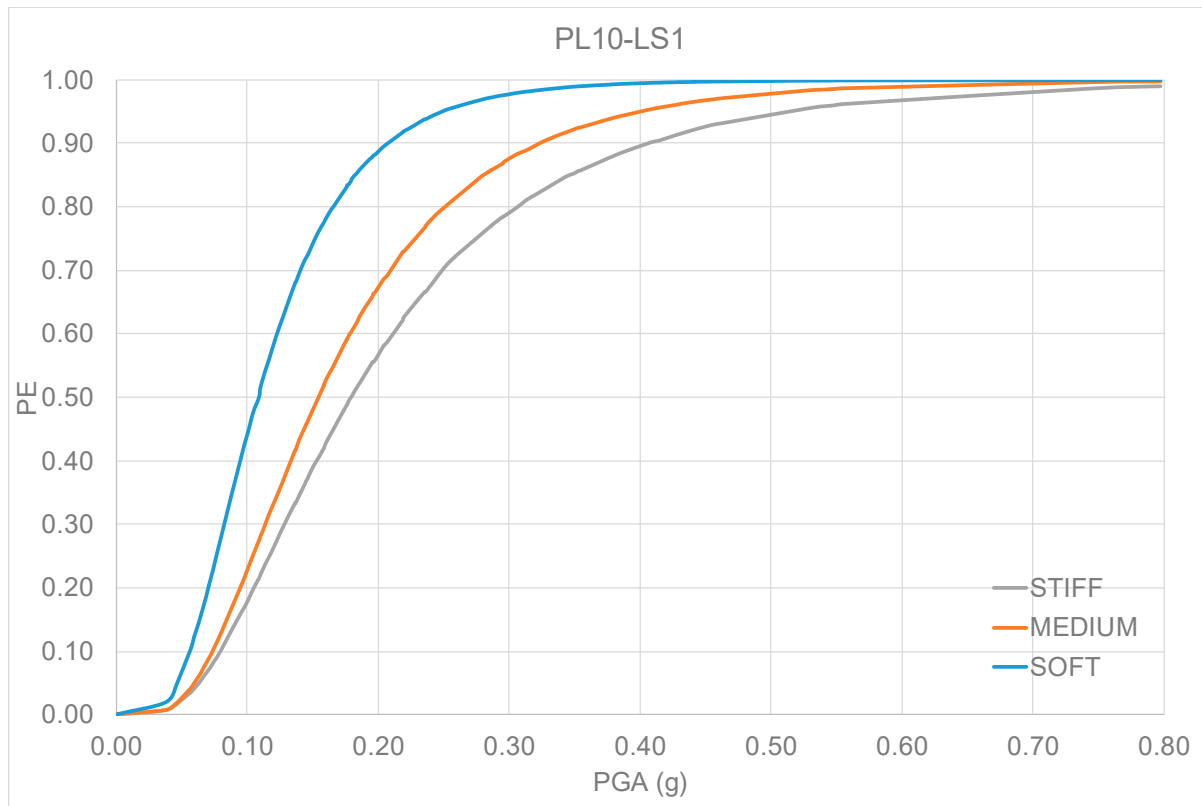

Figure 13. PL10-LS1 (various soil conditions): PGA (g) vs. Probability of exceedance (PE).

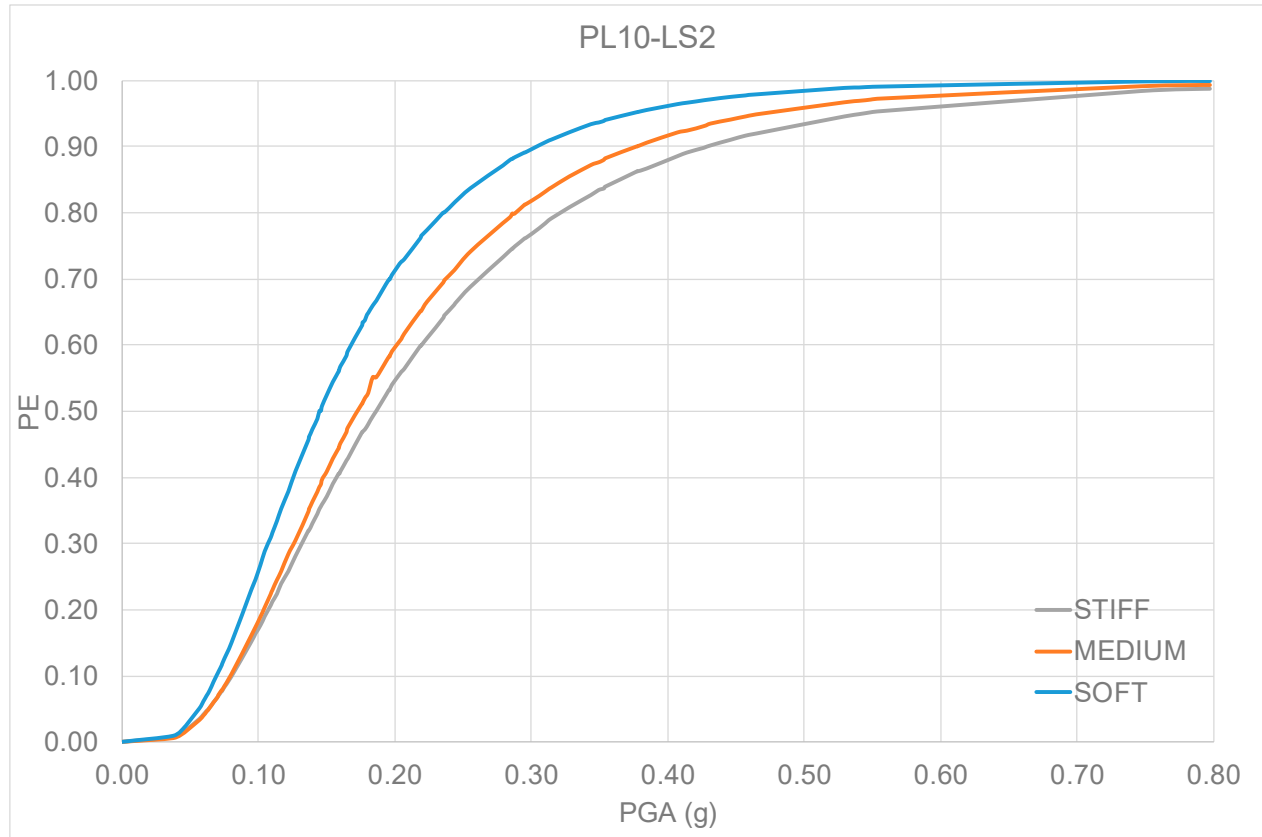

Figure 14. PL10-LS2 (various soil conditions): PGA (g) vs. Probability of exceedance (PE). 


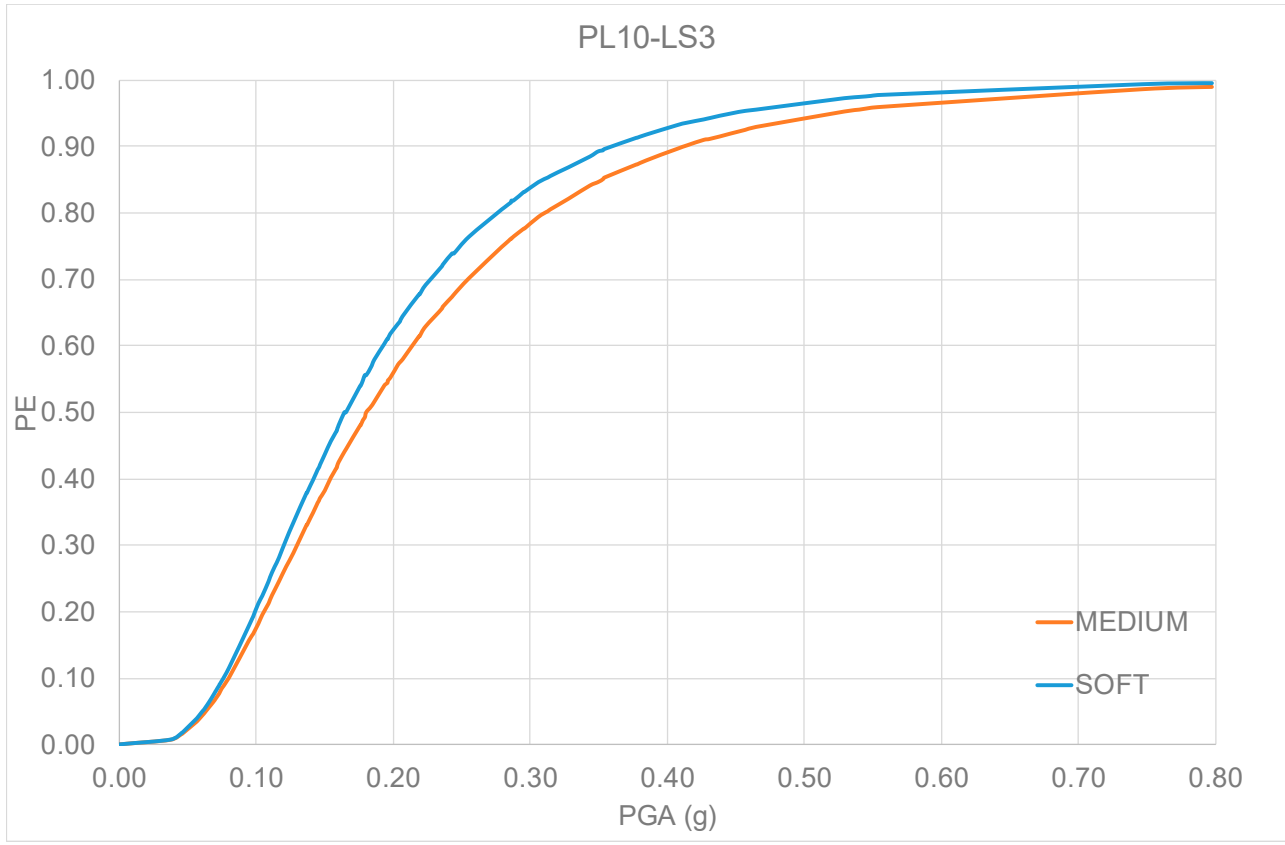

Figure 15. PL10-LS3 (various soil conditions): PGA (g) vs. Probability of exceedance (PE).

\subsection{PL5 and PL20}

Pile flexibility is herein considered by discussing the results for PL5 (the least flexible case) and PL20 (the most flexible case).

Figures 16-18 show that PL5 is more sensitive to soil conditions than PL10, in particular for LS1. The results also show that for soft and medium soil conditions, the values of PE are significantly distant for the various LS. In particular, for PGA $=0.10 \mathrm{~g}$ and LS1, PE values are $0.215,0.511$ and 0.836 , while for PGA $=0.20 \mathrm{~g}$ and LS2, PE values are: $0.203,0.648$ and 0.782 for stiff, medium and soft conditions respectively. PL5 under stiff conditions reaches LS3, as it is possible to see in Figures 7 and 18.

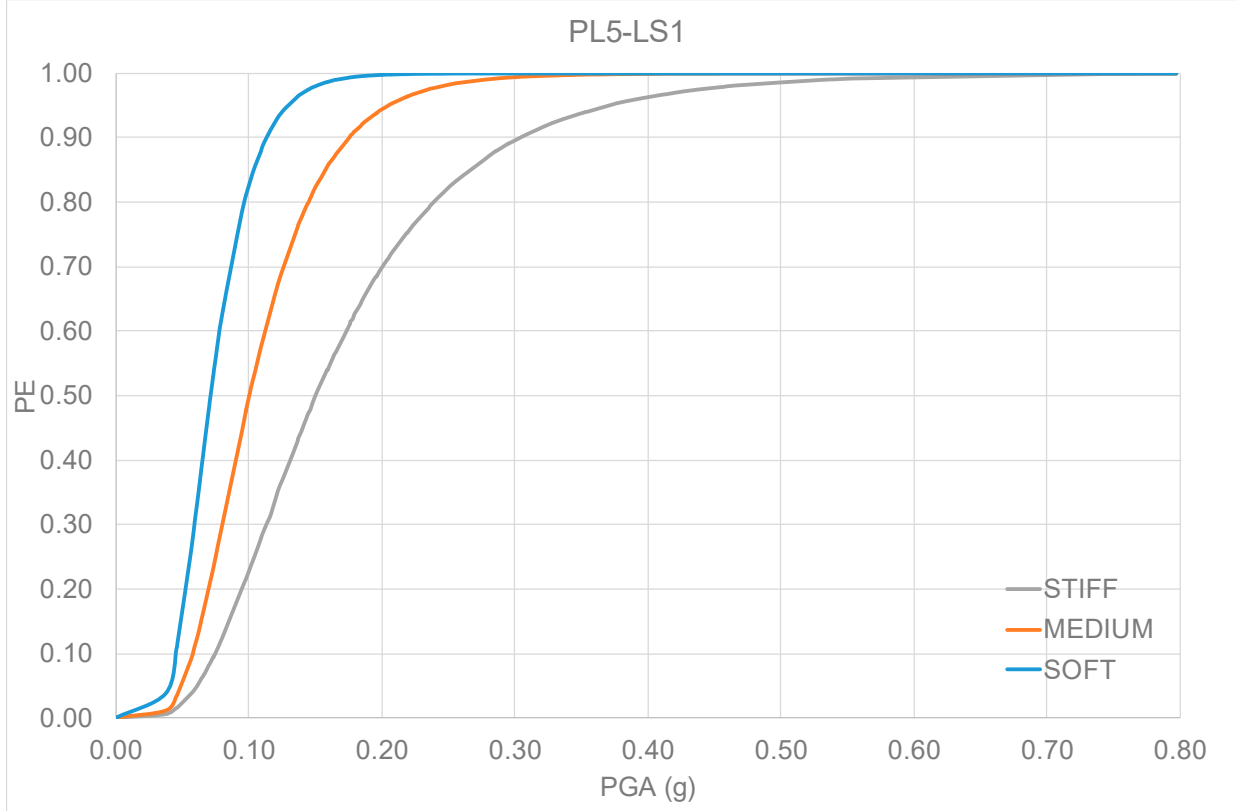

Figure 16. PL5-LS1 (various soil conditions): PGA (g) vs. Probability of exceedance (PE). 


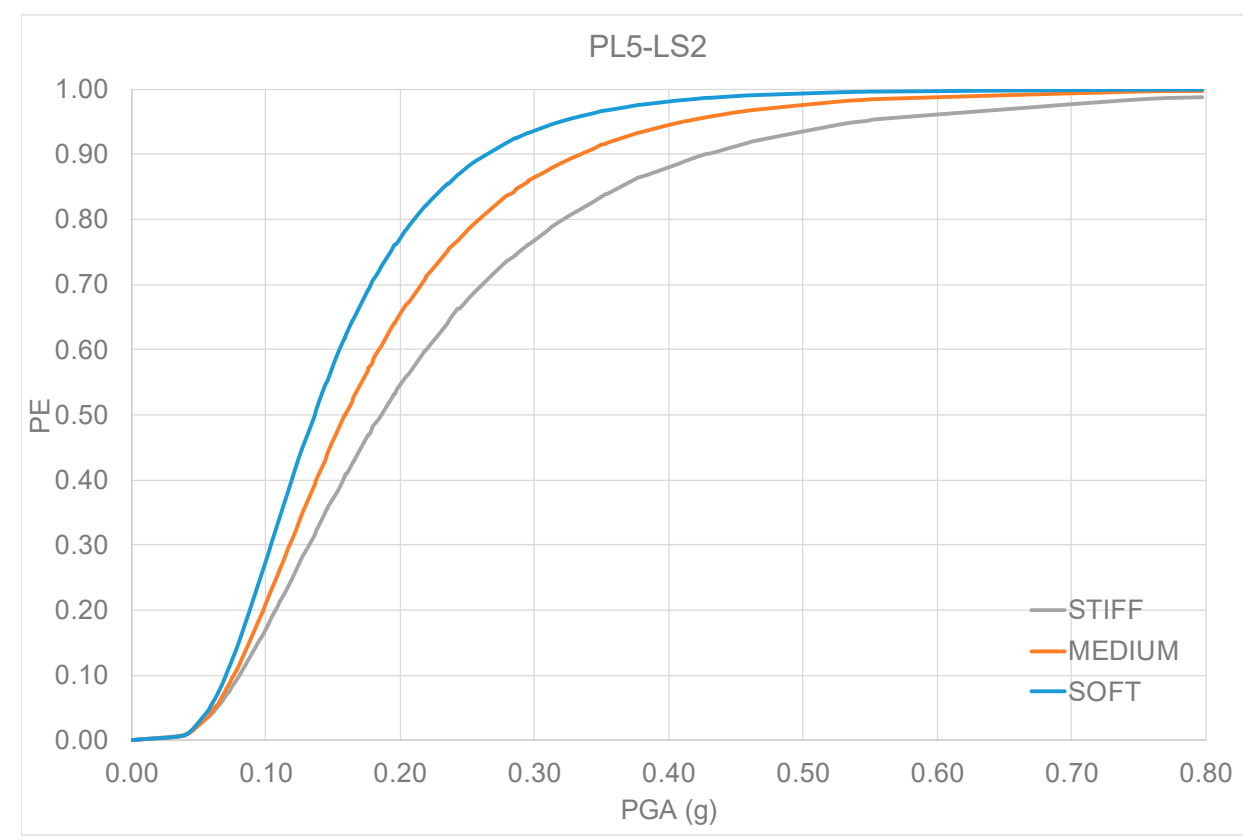

Figure 17. PL5-LS2 (various soil conditions): PGA (g) vs. Probability of exceedance (PE).

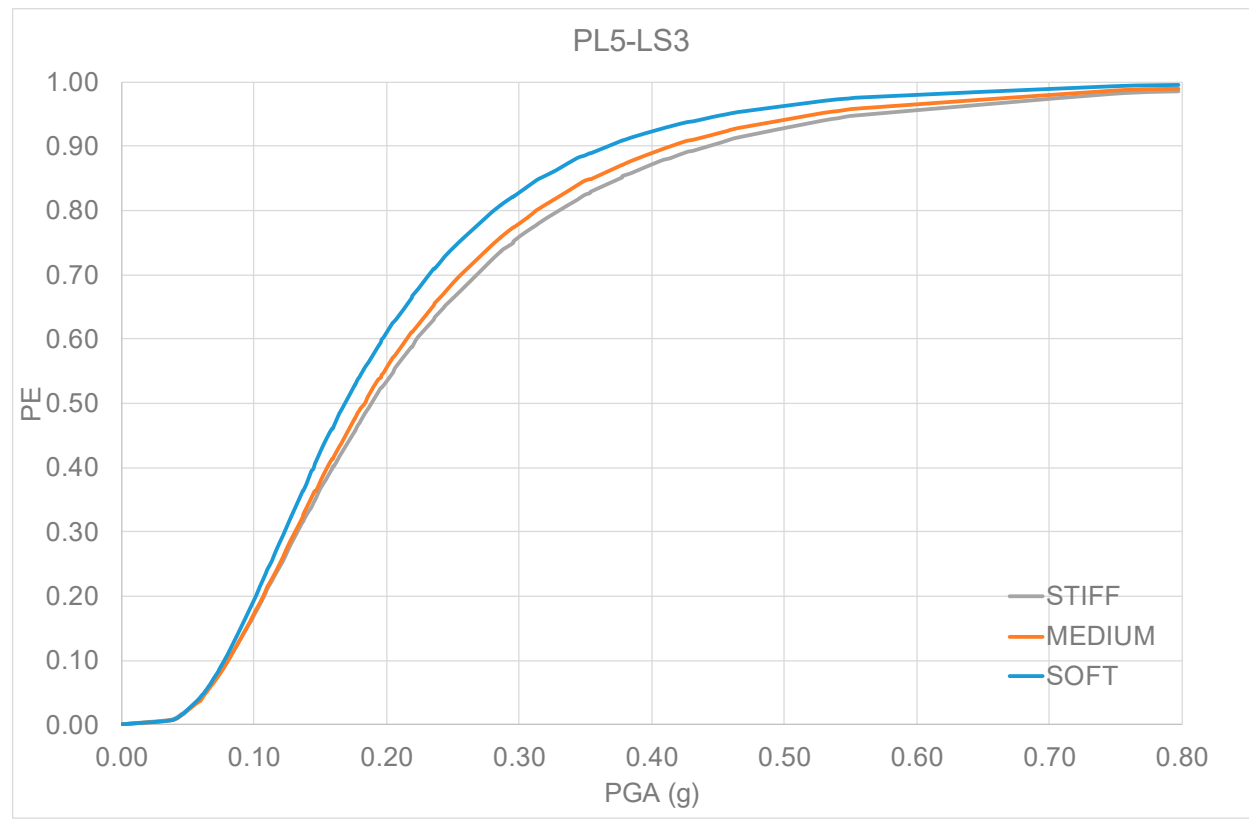

Figure 18. PL5-LS3 (various soil conditions): PGA (g) vs. Probability of exceedance (PE).

The results for PL20 (the most flexible case) are shown in Figures 19-21, where it is possible to see that for LS1 (Figure 19, slight damage), the curves are still different from each other, with mean values of $0.181 \mathrm{~g}, 136 \mathrm{~g}$, and $0.095 \mathrm{~g}$ for stiff, medium, and soft conditions, respectively. For LS2 (Figure 20), the values of probabilities for soft conditions are significantly different from those for medium and stiff conditions and this is true for all intensities. For example at PGA $=0.30 \mathrm{~g}, \mathrm{PE}$ are $0.749,0.788$, and 0.850 for stiff, medium, and soft conditions, respectively. Figure 21 shows that stiff conditions do not reach LS3 (compared with Figure 10), while the SSI effects are significant for all the intensities, with the maximum difference for PE are at $0.30 \mathrm{~g}$ with 0.749 and 0.850 for medium and soft conditions, respectively. 


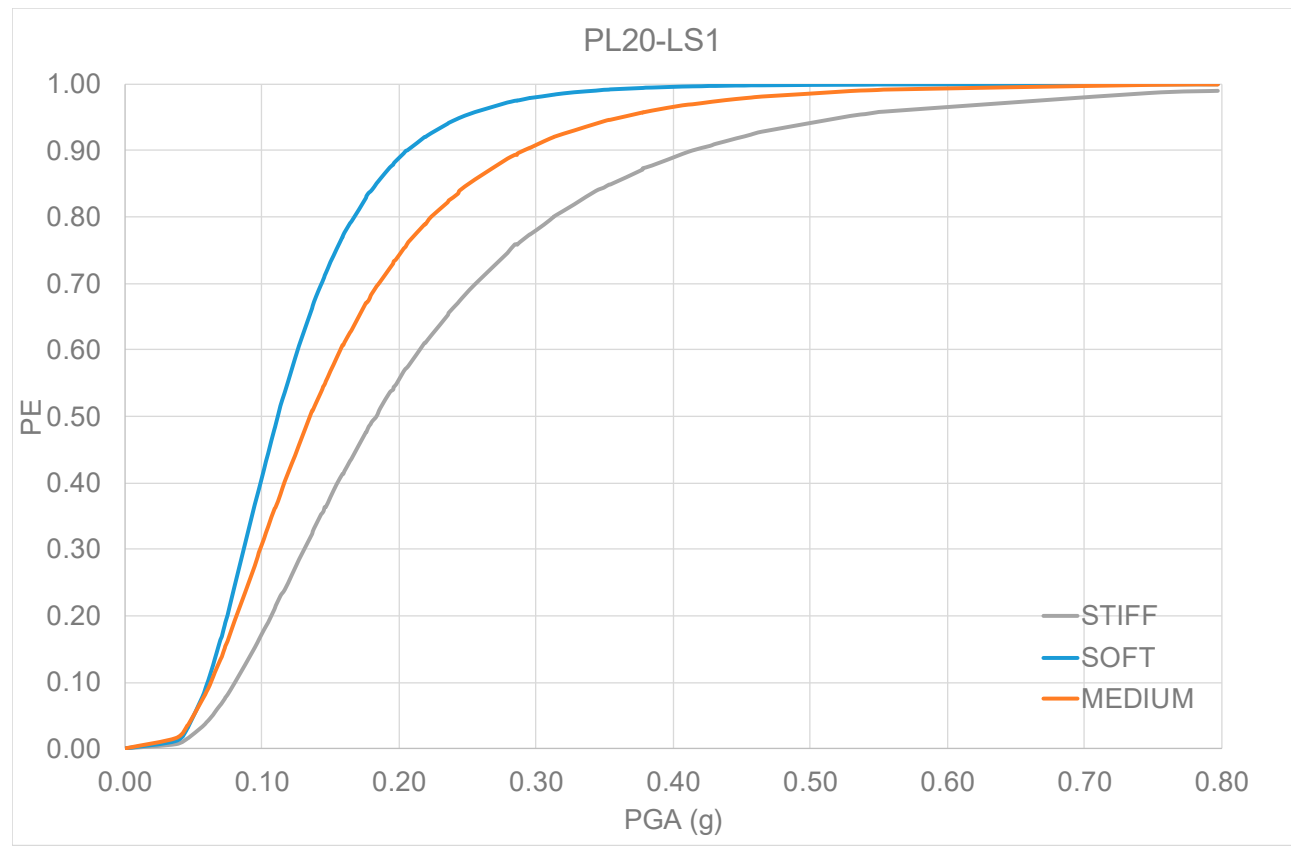

Figure 19. PL20-LS1 (various soil conditions): PGA (g) vs. Probability of exceedance (PE).

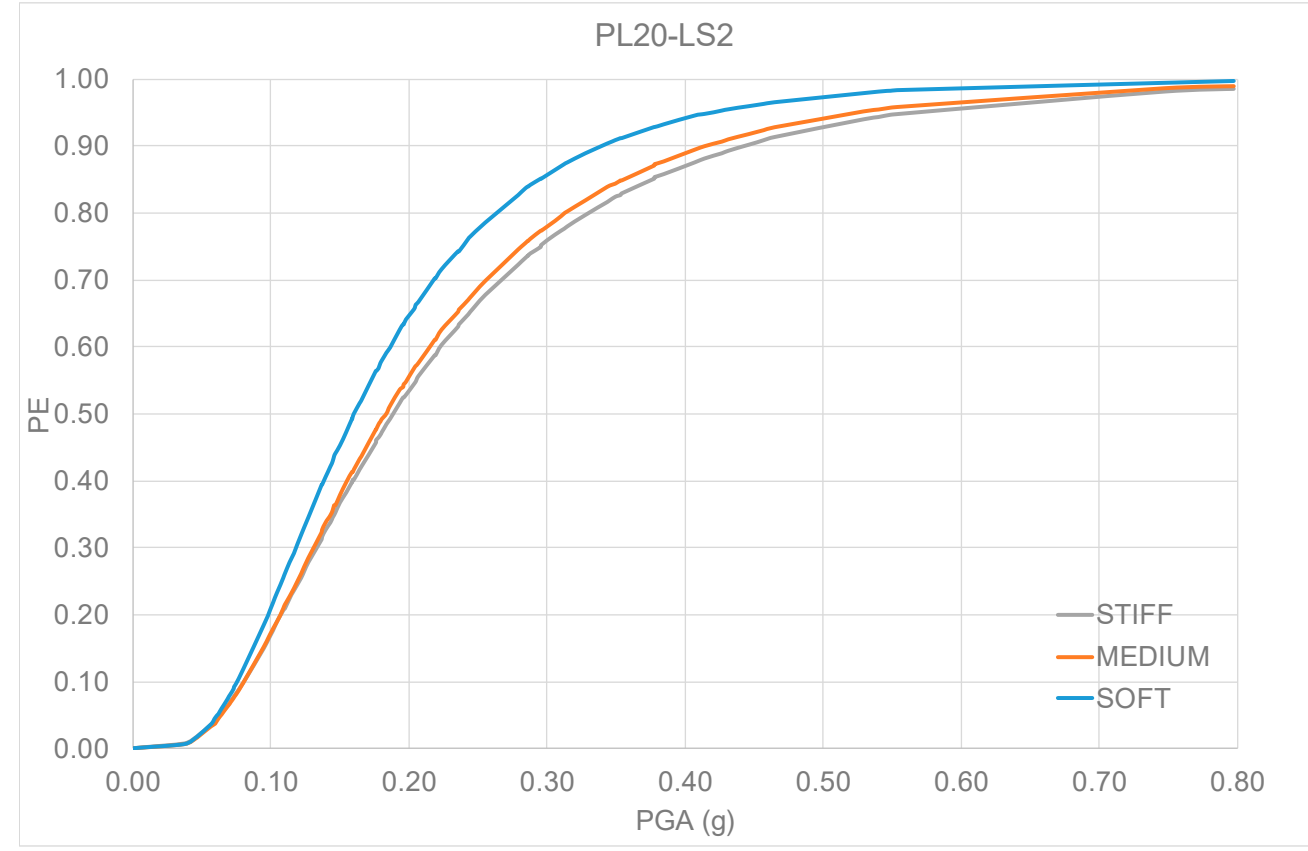

Figure 20. PL20-LS2 (various soil conditions): PGA (g) vs. Probability of exceedance (PE). 


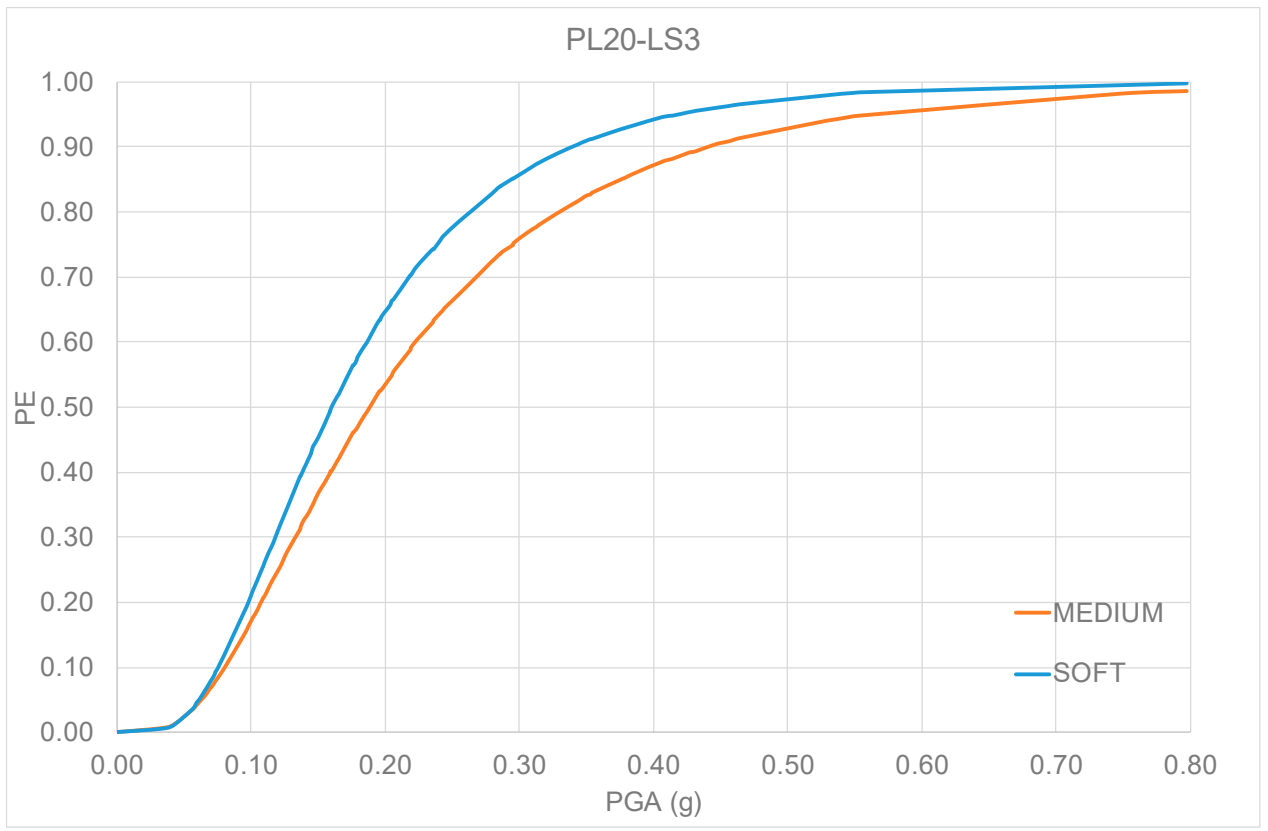

Figure 21. PL20-LS3 (various soil conditions): PGA (g) vs. Probability of exceedance (PE).

Figures 22-24 show the role of pile flexibility for several soil conditions at the intermediate level LS2 (DF = 1). When stiff conditions are considered, the flexibility of the pile does not seem to affect the fragility of the piles (same results for PL5, PL10, and PL20). For medium and soft soil conditions, the flexibility reduces pile vulnerability by shifting the curves toward less vulnerable behaviours (right part of the diagram). For example, for PGA $=0.25 \mathrm{~g}$, for medium conditions: $0.767,0.742$, and 0.674 while for soft conditions: $0.888,0.836$, and 0.764 , respectively, for PL5, PL10, and PL20 (see Table 8).

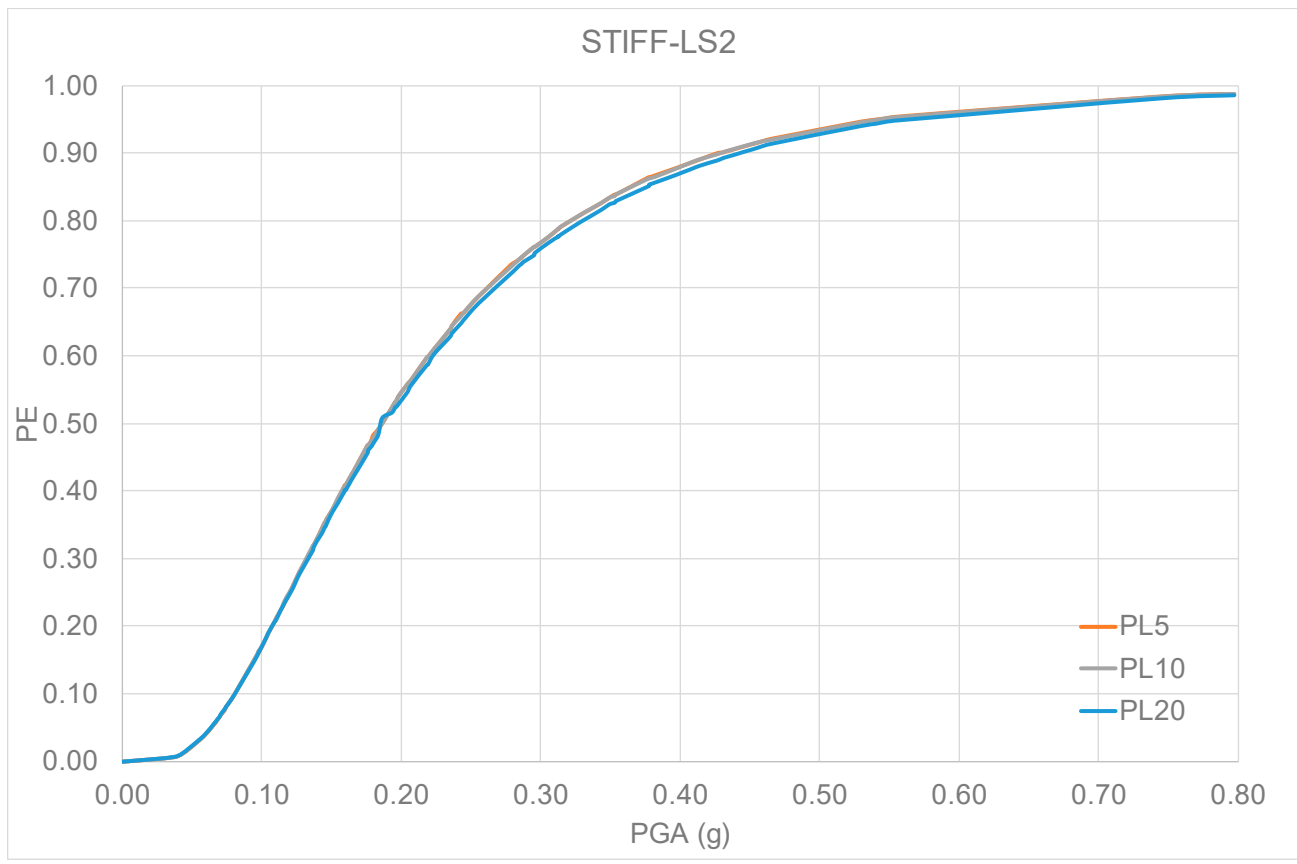

Figure 22. STIFF-LS2: PGA (g) vs. Probability of exceedance (PE). 


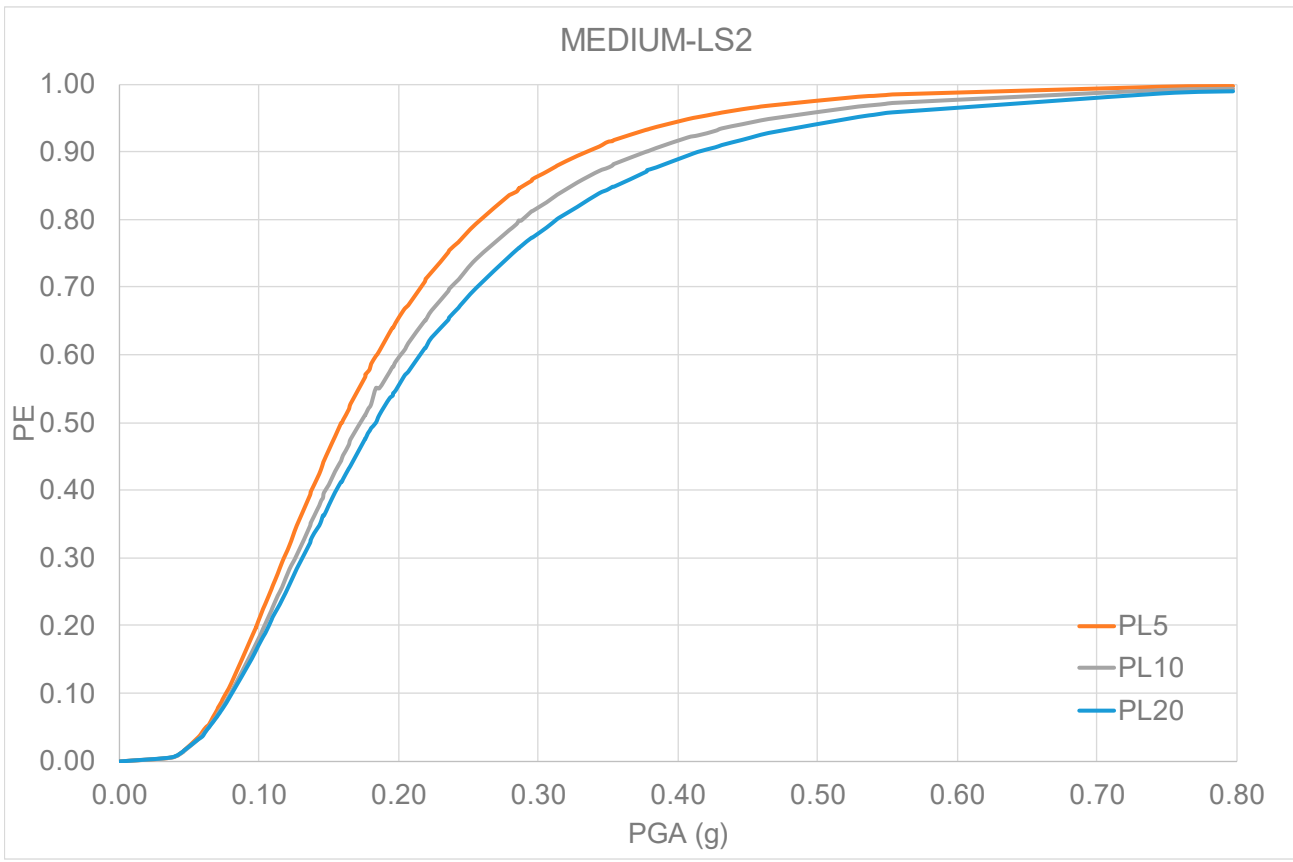

Figure 23. MEDIUM-LS2: PGA (g) vs. Probability of exceedance (PE).

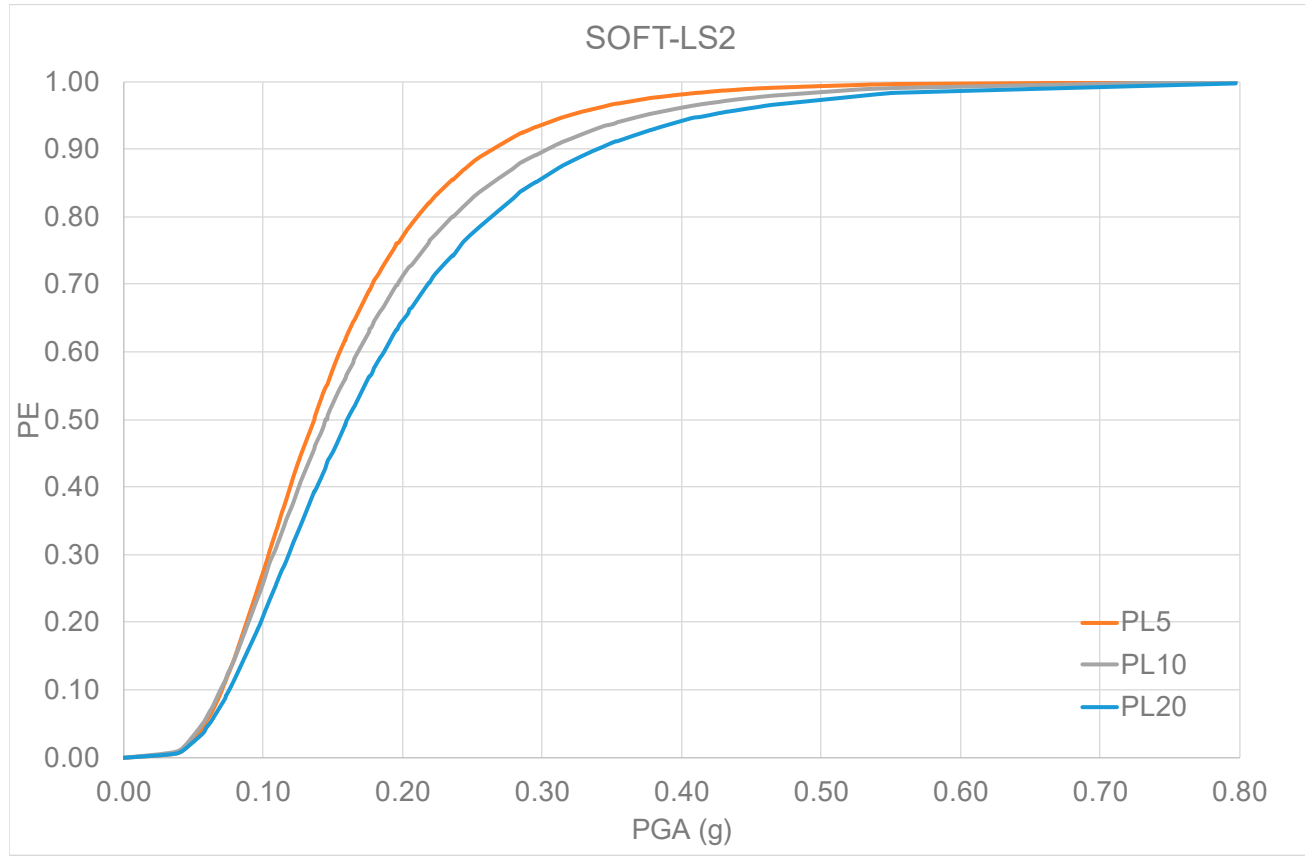

Figure 24. SOFT-LS2: PGA (g) vs. Probability of exceedance (PE).

Table 8. Comparison: PL5, PL10, and PL20 for MEDIUM and SOFT conditions (PGA $=0.25 \mathrm{~g}$ ).

\begin{tabular}{cccc}
\hline PE & PL5 & PL10 & PL20 \\
\hline MEDIUM & 0.767 & 0.742 & 0.675 \\
SOFT & 0.888 & 0.836 & 0.764 \\
\hline
\end{tabular}

\section{Conclusions}

The study conducted in this paper may be viewed as an original contribution to the seismic assessment of pile foundations with a probabilistic-based approach based 
on developing analytical fragility curves. The mutual effects of pile flexibility and SSI were considered by performing non-linear dynamic analyses on three pile configurations and three soil conditions (with increasing deformability). The FE computational model is based on an advanced constitutive formulation that enables to drive the assessment of the non-linear behaviour of the soil and of the piles. In particular, the paper assesses the role of pile flexibility on the performance of the soil-pile complex by referring to the ductility factor and three limit states that were proposed herein. In this regard, the ultimate aim of this study is to propose analytical fragility curves for the assessment of piles that may be applied to perform more typologies of configurations and different seismic conditions. This will be the objective of future work.

Author Contributions: Conceptualisation, D.F.; methodology, D.F.; software, D.F.; validation, D.F.; formal analysis, D.F.; investigation, D.F.; resources, D.F.; data curation, D.F.; writing-original draft preparation, D.F.; writing — review and editing, D.F.; visualisation, D.F.; supervision, D.F.; project administration, D.F.; funding acquisition, D.F. The author has read and agreed to the published version of the manuscript.

Funding: This research received no external funding.

Institutional Review Board Statement: Not applicable.

Informed Consent Statement: Not applicable.

Data Availability Statement: Not applicable.

Conflicts of Interest: The authors declare no conflict of interest.

\section{References}

1. Prakash, S.; Sharma, H.D. Pile Foundation in Engineering Practice; Wiley-Interscience: New York, NY, USA, 1990.

2. Reese, L.C.; Van Impe, W.E. Single Piles and Pile Groups under Lateral Loading; Balkema: Rotterdam, The Netherland, 2001.

3. Song, S.T.; Chai, Y.; Hale, T.H. Analytical model for ductility assessment of fixed-head concrete piles. J. Struct. Eng. 2005, 131, 1051-1059. [CrossRef]

4. Earthquake Engineering Research Center (EERC). Geotechnical Reconnaissance of the Effect of the January 17, 1995 Hyogoken-Nambu Earthquake, Japan; Report No. UCB/EERC-95/01; University of California: Berkeley, CA, USA, 1995.

5. Earthquake Engineering Research Institute (EERI). Koceali, Turkey Earthquake of August 17, 1999; Reconnaissance Report; Earthquake Spectra: Oakland, CA, USA, 2000.

6. Makris, N.; Badoni, D.; Delis, E.; Gazetas, G. Prediction of Observed Bridge Response with Soil-Pile-Structure Interaction. J. Struct. Eng. 1994, 120, 2992-3011. [CrossRef]

7. Applied Technology Council (ATC). Improved Seismic Design Criteria for California Bridges: Provisional Recommendations, ATC-32; Applied Technology Council: Redwood City, CA, USA, 1996.

8. New Zealand Transport Agency (NZTA). Bridge Manual; NZ Transport Agency: Willington, New Zealand, 2013.

9. Horikoshi, K.; Matsumoto, T.; Hashizume, Y.; Watanabe, T. Performance of piled raft foundations subjected to dynamic loading. Int. J. Phys. Model. Geotech. 2003, 3, 51-62. [CrossRef]

10. Baziar, M.H.; Rafiee, F.; Saeedi Azizkandi, A.; Lee, C.J. Effect of super-structure radial frequency on the seismic behavior of pile-raft foundation using physical modeling. Soil Dyn. Earthq. Eng. 2018, 104, 196-209. [CrossRef]

11. Matsumoto, T.; Fukumura, K.; Pastsakorn, K.; Horikoshi, K.; Oki, A. Experimental and analytical study on behaviour of model piled rafts in sand subjected to horizontal and moment loading. Int. J. Phys. Model. Geotech. 2004, 4, 1-19. [CrossRef]

12. Roy, J.; Kumarc, A.; Choudhurya, D. Natural frequencies of piled raft foundation including superstructure effect. Soil Dyn. Earthq. Eng. 2018, 112, 69-75. [CrossRef]

13. Gazetas, G.; Dobry, R. Horizontal response of piles in layered soils. J. Geotech. Eng. 1984, 110, 20-40. [CrossRef]

14. Budek, A.M.; Benzoni, G. Obtaining ductile performance from precast, prestressed concrete piles. PCI J. 2009, 54, 64-80. [CrossRef]

15. Budek, A.M.; Priestley, M.J.N.; Benzoni, G. Inelastic Seismic Response of Bridge Drilled-Shaft RC Pile/Columns. J. Struct. Eng. 2000, 126, 510-517. [CrossRef]

16. Chai, Y.H.; Hutchinson, T.C. Flexural strength and ductility of extended pile-shafts II: Experimental study. J. Struct. Eng. 2002, 128, 595-602. [CrossRef]

17. Hutchinson, T.C.; Boulanger, R.W.; Chai, Y.H.; Idriss, I.M. Inelastic Seismic Response of Extended Pile-Shaft-Supported Bridge Structures. Earthq. Spectra 2004, 20, 1057-1080. [CrossRef]

18. Chiou, J.S.; Tsai, Y.C.; Chen, C.H. Simple estimation for ductility capacity of a fixed-head pile in cohesive soils. Can. Geotech. J. 2011, 48, 1449-1460. [CrossRef] 
19. Chiou, J.S.; Tsai, Y.C.; Chen, C.H. Investigating influencing factors on the ductility capacity of a fixed-head reinforced concrete pile in homogeneous clay. J. Mech. 2012, 28, 489-498. [CrossRef]

20. Kumar, A.; Choudhury, D.; Katzenbach, A. Effect of earthquake on combined pile-raft foundation. Int. J. Geomech. 2016, 16, 04016013. [CrossRef]

21. Kumar, A.; Choudhury, D. Load sharing mechanism of combined pile-raft foundation under seismic loads. Geotech. Eng. 2017, 48, 95-101.

22. Kumar, A.; Choudhury, D.; Shukla, J.; Shah, D.L. Seismic design of pile foundation for oil tank by using PLAXIS3D. Disaster Adv. 2015, 8, 33-42.

23. Arulmoli, K.; Martin, G.R.; Gasparro, M.G.; Shahrestani, S.; Buzzoni, G. Design of pile foundations for liquefaction-induced lateral spread displacements. In Geotechnical Engineering for Transportation Projects; Geo-Trans 2004: Los Angeles, CA, USA, 2004; pp. 1673-1681. [CrossRef]

24. Shafieezadeh, A.; DesRoches, R.; Rix, G.J.; Werner, S.D. Seismic performance of pile-supported wharf structures considering soil-structure interaction in liquefied soil. Earthq. Spectra 2012, 28, 729-757. [CrossRef]

25. Chiaramonte, M.M.; Arduino, P.; Lehman, D.E.; Roeder, C.W. Seismic analyses of conventional and improved marginal wharves. Earthq. Eng. Struct. Dyn. 2013, 42, 1435-1450. [CrossRef]

26. Donahue, M.J.; Dickenson, S.E.; Miller, T.H.; Yim, S.C. Comparison of 3D modeling to recorded seismic response for a pile supported wharf. In Proceedings of the Ports Conference 2004, Houston, TX, USA, 23-26 May 2004; pp. 1-10.

27. Doran, B.; Shen, J.H.; Akbas, B. Seismic evaluation of existing wharf structures subjected to earthquake excitation: Case study. Earthq. Spectra 2015, 31, 1177-1194. [CrossRef]

28. Elgamal, A.; Lu, J.; Forcellini, D. Mitigation of liquefaction-induced lateral deformation in a sloping stratum: Three-dimensional Numerical Simulation. J. Geotech. Geoenviron. Eng. 2009, 135, 1672-1682. [CrossRef]

29. Su, L.; Lu, J.; Elgamal, A.; Arumoli, A.K. Seismic performance of a pile-supported wharf: Three-dimensional finite element simulation. Soil Dyn. Earthq. Eng. 2017, 95, 167-179. [CrossRef]

30. Song, S.T.; Wang, C.Y.; Hu, T.F. Displacement Ductility Limits for Pile Foundations in Cohesionless Soils. J. Earthq. Eng. 2017, 22, 595-629. [CrossRef]

31. Badry, P.; Satyam, N. An efficient approach for assessing the seismic soil structure interaction effect for the asymmetrical pile group. Innov. Infrastruct. Solut. 2016, 1, 8. [CrossRef]

32. Okada, T.; Fujita, K.; Takewaki, I. Robustness evaluation of seismic pile response considering uncertainty mechanism of soil properties. Innov. Infrastruct. Solut. 2016, 1, 5. [CrossRef]

33. Sarkar, R.; Roy, N.; Serawat, A. A three dimensional comparative study of seismic behaviour of vertical and batter pile groups Geotech. Geol. Eng. 2017, 36, 763-781. [CrossRef]

34. Yuan, H.; Li, Y. Downdrag force analysis for seismic soil-pile-structure interaction. Geotech. Geol. Eng. 2017, 35, 493-501. [CrossRef]

35. Azizkandi, A.S.; Baziar, M.H.; Yeznabad, A.F. 3D dynamic finite element analyses and $1 \mathrm{~g}$ shaking table tests on seismic performance of connected and nonconnected piled raft foundations. KSCE J. Civ. Eng. 2017, 22, 1750-1762. [CrossRef]

36. Visuvasam, J.; Chandrasekaran, S.S. Effect of soil-pile-structure interaction on seismic behaviour of RC building frames. Innov. Infrastruct. Solut. 2019, 4, 45. [CrossRef]

37. Forcellini, D. A Resilience-Based Methodology to Assess Soil Structure Interaction on a Benchmark Bridge. Infrastructures 2020, 5, 90. [CrossRef]

38. Forcellini, D. Probabilistic-based assessment of Liquefaction-Induced damage with analytical fragility curves. Geosciences 2020, 10, 315. [CrossRef]

39. Mina, D.; Forcellini, D.; Karampour, H. Analytical fragility curves for assessment of the seismic vulnerability of HP/HT unburied subsea pipelines. Soil Dyn. Earthq. Eng. 2020, 137, 106308. [CrossRef]

40. Forcellini, D. Analytical fragility curves of shallow-founded structures subjected to Soil-Structure Interaction (SSI) effects. Soil Dyn. Earthq. Eng. 2020, 141, 106487. [CrossRef]

41. Yang, C.S.W.; Desroches, R.; Rix, G.J. Numerical fragility analysis of vertical-pile-supported wharves in the western United States. J. Earthq. Eng. 2012, 16, 579-594. [CrossRef]

42. Mitropoulou, C.C.; Kostopanagiotis, C.; Kopanos, M.; Ioakim, D.; Lagaros, N.D. Infuence of soil-structure interaction on fragility assessment of building structures. Structures 2016, 6, 85-98. [CrossRef]

43. Ko, Y.; Yang, H. Deriving seismic fragility curves for sheet-pile wharves using finite element analysis. Soil Dyn. Earthq. Eng. 2019, 123, 265-277. [CrossRef]

44. Cavalieri, F.; Correia, A.; Crowley, H.; Pinho, R. Seismic fragility analysis of URM buildings founded on piles: Influence of dynamic soil-structure interaction models. Bull. Earthq. Eng. 2020, 18, 4127-4156. [CrossRef]

45. Finn, W. A study of piles during earthquakes: Issues of design and analysis. Bull. Earthq. Eng. 2005, 3, 141-234. [CrossRef]

46. Forcellini, D. Cost Assessment of isolation technique applied to a benchmark bridge with soil structure interaction. Bull. Earthq. Eng. 2017, 15, 51-69. [CrossRef]

47. CEN, European Committee for Standardisation TC250/SC8/. Eurocode 8: Design Provisions for Earthquake Resistance of Structures; Part 1.1: General rules, seismic actions and rules for buildings, PrEN1998-1; European Committee for Standardisation: Bruxelles, Belgium, 2003. 
48. Lu, J.; Elgamal, A.; Yang, Z. OpenSeesPL: 3D Lateral Pile-Ground Interaction, User Manual, Beta 1.0. 2011. Available online: http:/ / soilquake.net/openseespl/ (accessed on 2 February 2021).

49. Law, H.K.; Lam, I.P. Application of periodic boundary for large pile group. J. Geotech. Geoenviron. Eng. 2001, 127, 889-892. [CrossRef]

50. Mazzoni, S.; McKenna, F.; Scott, M.H.; Fenves, G.L. Open System for Earthquake Engineering Simulation, User Command-Language Manual; OpenSees Version 2.0.; Pacific Earthquake Engineering Research Center, University of California: Berkeley, CA, USA, 2009; Available online: http:/ / opensees.berkeley.edu/OpenSees/manuals/usermanual (accessed on 2 February 2021).

51. Forcellini, D. Soil-structure interaction analyses of shallow-founded structures on a potential-liquefiable soil deposit. Soil Dyn. Earthq. Eng. 2020, 133, 106108. [CrossRef]

52. Forcellini, D. Numerical simulations of liquefaction on an ordinary building during Italian (20 May 2012) earthquake. Bull. Earthq. Eng. 2019, 17, 4797-4823. [CrossRef]

53. Kuhlemeyer, R.L.; Lysmer, J. Finite element method accuracy for wave propagation problems. J. Soil Mech. Found. Div. 1973, $99,421-427$

54. Sharma, N.; Dasgupta, K.; Dey, A. Optimum lateral extent of soil domain for dynamic SSI analysis of RC framed buildings on pile foundations. Front. Struct. Civ. Eng. 2020, 14, 62-81. [CrossRef]

55. Lysmer, J.; Kuhlemeyer, R.L. Finite dynamic model for in finite media. J. Eng. Mech. Div. 1969, 95, 859-878.

56. Prevost, J.H. A simple plasticity theory for frictional cohesionless soils. Int. J. Soil Dyn. Earthq. Eng. 1985, 4, 9-17. [CrossRef] 